This is a PDF file of an unedited manuscript that has been accepted for publication in Energy Strategy Reviews. The manuscript will undergo copyediting, typesetting, and review of the resulting proof before it is published in its final form. Please note that during the production process errors may be discovered which could affect the content, and all legal disclaimers that apply to the journal pertain.

The final version will be available at: https://doi.org/10.1016/j.esr.2018.05.004

\title{
Identification of objectives for national energy planning in developing countries
}

Lee, N.C. ${ }^{a, b, 1}$, Leal, V.M.S. ${ }^{a, b}$ and Dias L.C. ${ }^{c, d}$

${ }^{a}$ Institute of Mechanical Engineering and Industrial Management (INEGI), Rua Dr. Roberto Frias, 400. 4200-465 Porto, Portugal;

${ }^{b}$ Faculty of Engineering, University of Porto (FEUP), Rua Dr. Roberto Frias. 4200-465 Porto, Portugal;

${ }^{\mathrm{C}}$ Centre for Business and Economics Research (CeBER) and Faculty of Economics, University of Coimbra, Av. Dias da Silva 165, 3004-512 Coimbra, Portugal;

dInstitute for Systems Engineering and Computers (INESC), Rua Sílvio Lima, Pólo II, 3030-290 Coimbra, Portugal;

\section{Abstract}

Defining objectives is an essential part of planning processes, useful to induce creative alternatives and to derive the attributes (criteria) on which the alternatives will be assessed. This article identifies a set of energy planning (EP) objectives and measurable attributes specifically tailored for promoting sustainability in developing countries. A literature review was conducted as part of a problem structuring activity to identify applicable EP objectives. The Economic Community of West African States (ECOWAS), with an emphasis on Ghana, was used as a representative area of study. Two EP objectives specific to the context of the ECOWAS were identified, namely, to maximize the maintainability of the final energy supply system and to maximize the access to final energy services. These were included within a set of EP objectives which consisted of the additional objectives to maximize primary energy security, to maximize the reliability of the final energy system, to minimize costs (investment, operation \& maintenance), to minimize the influence of the energy system on the global climate, and to minimize the impact of the energy system on the local environment. These EP objectives were made operational through the identification of a set of corresponding measurable attributes. This EP objective set, used within a structured EP methodology, may support the implementation and sustainability of national EP activities in the countries of the region.

\section{Highlights}

- Identifies energy planning objectives and attributes for developing countries

- Energy planning objectives may support plan implementation in the ECOWAS

- Two unique energy planning objectives were made explicit in problem structuring

- One unique objective was maximizing the maintainability of the final energy system

- Evaluation of achievement of objectives realized through quantifiable attributes

Keywords: Energy planning; Developing countries; Multi-attribute/Multi-criteria decision analysis; Problem structuring; Economic Community of West African States (ECOWAS)

Abbreviations: decision makers (DMs); developed country (Dev-C); Economic Community of West African States (ECOWAS); energy planning (EP); energy security attribute (ESA); final energy (FE); greenhouse gas (GHG); Intergovernmental Panel on

\footnotetext{
1 Corresponding author - nathan.lee@fe.up.pt; Present address: National Renewable Energy Laboratory (NREL), 15013 Denver West Parkway, Golden, CO 80401, USA
} 
Climate Change (IPCC); primary energy (PE); problem structuring methods (PSMs); Strategic National Energy Plan (SNEP); Sub-Saharan Africa (SSA); urban core population (CoreUrban); urban periphery population (PeriUrban); United States dollars (US\$)

\section{Introduction}

Developing countries are facing formidable challenges to economic and human development for which energy plays an essential role [1]. Energy planning (EP) is an essential activity in the establishment of an energy trajectory which meets society's demands for final energy (FE) services and supports the achievement of national development objectives.

The EP practices of the countries of Sub-Saharan Africa (SSA) remain relatively nascent in comparison to those of more developed countries and frequently lack the frameworks necessary to support energy policy development [2]. The EP practices of the Economic Community of West African States (ECOWAS), in particular, have been hindered by largely nonexistent or weakly implemented institutional structures and frameworks [3]. The absence of adequate EP frameworks can lead to deficient, ad-hoc, and short-term decision making in the place of coherent medium to long-term EP [2]. The lack of adequate EP activities also adversely affects the successful development of energy strategies and the implementation of the resulting energy projects [3].

Innovative EP and policy development frameworks are required in order to set and achieve medium to long-term EP objectives. These must establish coherent policies with precise targets and be based on clearly detailed EP strategies [4]. One component of these frameworks is the identification and use of a set of EP objectives that are specific to the context of application. A review of EP activities of members of the ECOWAS by Lee and Leal [5] found that EP activities of countries in the region employed EP objectives which resembled those common to EP activities of developed countries. It was, however, unclear if this convergence of objectives represented a fundamental nature or if it represented the appropriation of objectives without the comprehensive bottom-up activity of identifying the fundamental objectives applicable to each EP activity. The EP objectives of developed countries fall into the "three E" themes of energy security, economic development, and environmental protection [6]. A recent work from Haydt et al. [7] on energy efficiency planning in Portugal identified a set of six objectives comprising (1) minimizing impact on global climate, (2) minimizing investment risks, (3) maximizing energy security, (4) minimizing risk of plan failure, (5) minimizing the time until the effect of the plan, and (6) minimized investment costs.

The purpose of the current work was to identify a set of EP objectives and quantifiable attributes which were specific to the context of application and influential for the implementation and sustainability of energy sector plans and to employ these in a case study evaluation. The ECOWAS, with an emphasis on Ghana, was used as a representative sample of developing countries in SSA. Currently, a bottom-up process to identify context specific objectives and corresponding quantifiable attributes that enables the assessment and choice of attractive national EP alternatives (policy options) appears to be absent in the current EP practices of the region [8]. This work proposes an extended methodology to identify objectives, operationalize these objectives with quantifiable attributes, and compute these attributes with existing data sources. This methodology may be beneficial in EP activities of countries in the region and possibly for those of other developing countries.

Defining objectives is an essential part of planning processes, useful for inducing creative alternatives and deriving the attributes (criteria) on which the alternatives will be assessed. This often includes several possibly conflicting economic, environmental, and practical (e.g., technology availability) objectives [9]. Problem structuring methods (PSMs), also referred to as soft operational research methods were developed from efforts to ensure that a holistic approach was used to account for the widening boundaries of problems as well as the multiple actors - often excluded from purely quantitative operational research methods. PSMs aid in managing rather than reducing complex issues and are helpful in reaching a comprehensive understanding of situations and reaching a common definition of the problem [10,11]. Literature on the use of PSMs in real-world EP activities is rapidly growing. The use of PSMs in EP is often a multi-methodology approach for structuring in support of decision problems. Neves et al. [12] employed PSMs for identifying the key issues, objective 
hierarchy, and means-ends network for structuring objectives and attributes in the development of a generic multi-criteria decision analysis (MCDA) model for use in evaluation of energy efficiency initiatives. Neves et al. [13] developed a cognitive and causal map in addition to an objectives hierarchy to support an evaluation of alternatives with a MCDA model. Haydt et al. [7] used the Delphi method to identify relevant EP objectives as well as the value-focused thinking approach from Keeney [14] to structure the objectives and quantifiable attributes for energy efficiency planning. Recently, Antunes et al. [15] employed the value-focused thinking approach to frame the problem of evaluating technological innovations and incentive policies in the electricity sector.

The current work employs the value-focused thinking approach to identify the fundamental objectives, and corresponding quantifiable attributes for national EP activities in the ECOWAS. The structuring of decision problems also includes the steps of selecting appropriate structures (e.g., a decision tree structure or a multiple objective structure) and the refinement of these structures (e.g., defining fundamental objectives and quantifiable attributes) [16]. Problem structuring in the current work was conducted in support of a decision analysis problem and consisted of the three steps of (1) framing or identification, (2) development of a structure and (3) refinement of this structure [16].

The term EP is used to cover a number of activities in the energy sector. This work considers the EP activity in developing countries with a focus on ECOWAS member states for a medium-term planning horizon (5-20 years for example). A medium-time horizon permits time for the purchase and installation of infrastructure which potentially requires a number of years, as is the case for electrical energy systems. The medium-term horizon is evaluated here in annual time slices allowing for an understanding of the state of the energy system in each year. The current work concentrates on technical measures as opposed to policies and subsidy programs established by governments and utilities. The costs for energy use (e.g., electricity) can be divided into the actual costs for generation and delivery of energy carriers and the margin above these costs which provide profits to utilities and governments. As the profit margin is dependent on government and utility policies or subsidy programs this remained outside of the technical focus of this current work. This technical focus also applies to technical energy sector planning activities as opposed to implementation mechanisms, such as financial incentives or information programs. Although it is acknowledged that promotional mechanisms are influential in the implementation of energy plans, there are many possible implementation mechanisms and these are often context specific.

Section 2, which follows, details the framing stage where a detailed literature review was completed to identify potential implicit and explicit factors important for EP in developing countries. Section 3 describes the structuring phase, where the value focused thinking approach was beneficial in structuring the EP objectives into a hierarchy of fundamental objectives and a network of means-ends objectives. In Section 4, the refinement phase, the scope of each of the EP objectives was defined and quantifiable attributes were identified. A reference "business as usual" projection, for a case study of Ghana is evaluated with this set of objectives and corresponding attributes in Section 5. A discussion of the EP objectives, corresponding attributes, and the case study is presented in Section 6.

\section{Framing the problem}

To identify a set of objectives specific to the context of EP in the ECOWAS, a literature review was initially completed to identify factors considered influential in the implementation and sustainability of energy sector plans and projects in developing countries. Following this literature review a consultation with stakeholders was conducted as part of the case study (Section 5) to verify the EP objectives.

The reviewed literature consisted of 18 scientific articles, 8 reports from governments, organizations and one company, and finally 5 news articles, presented in Appendix A. This literature review resulted in the identification of a preliminary set of 109 factors. A filtration process was then conducted to establish a final set of factors. A flow-chart detailing the literature review and the filtration process is presented in Fig. 1. The full set of factors and the filtration process is also detailed in Fig. A 1 of Appendix A. 


\section{(1.5-column fitting image)}

Fig. 1. Flowchart of literature review of implementation and sustainability factors

The filtration process began with an initial screening of factors to eliminate redundant or duplicate factors. The factors were then evaluated in terms of their capacity to be developed into an objective rather than being characteristic of a constraint. Constraint type factors can be described as "yes/no" conditions (e.g., availability of funds, as opposed to an objective type factor such as minimizing costs). This resulted in a list of 43 factors after the removal of 66 factors. Several of the identified factors concerned implementation mechanisms, such as financial incentives or information programs, rather than technical measures, considered out of the scope of this work as described in Section 1. Focusing on factors related with technical measures resulted in a list of 11 factors. Next, factors considered circumstantial to EP efforts as opposed to fundamental factors, such as government support for actions, were filtered out. The list consisted of nine factors after removing circumstantial factors. Finally, similar factors which could be expressed within a more general single factor were combined to produce a final list of seven factors. An example of similar factors combined to form a single factor (as opposed to redundant factors described previously) consisted of "Availability of technical know-how" and "Availability of maintenance and servicing resources and facilities" which were combined to form the final factor of "Maintainability of energy systems". The final seven factors are presented in Table 1 and are separated into factors specific to technologies or systems, economic and financial considerations, and environmental concerns. The majority of the factors corresponded to the first of these themes.

Table 1. List of factors for implementation and sustainability

\section{Structuring the problem}

The factors identified in the framing phase (Table 1), at this stage, were not in operational EP objective forms. It was therefore necessary to translate these factors into EP objectives and to structure them into a hierarchy of fundamental objectives and a network of means-ends objectives following Keeney [14].

The terms objective, goal, and target are frequently used interchangeably in colloquial language. The term objective here, following Keeney [14], refers to a statement of what is hoped to be achieved. It requires three components: a decision context, an object, and a direction of preference. For example, an EP objective may be to "Minimize greenhouse gas (GHG) emissions." The decision context is the EP activity, the object is GHG emissions (possibly the impact on global climate), and the preference is for less GHG emissions as opposed to more. In contrast to this, the terms target and goal refer to the introduction of a specific level or standard in the measurement system in regards to an objective. The goal or target is either achieved or not achieved. An example of a target or goal would be to decrease the GHG equivalent emissions to 20 kton of $\mathrm{CO}_{2 \text { eq }}$ by the end of the planning horizon. The use of targets and goals are common in EP activities, and the current work does not intend to diminish their importance; however, it is important to make a distinction between the terms here.

The objectives include both fundamental and means objectives. Fundamental objectives are those that are both essential and controllable, while means objectives are those which are important due to their implications for other higher level objectives [14]. Fundamental and means objectives can be identified through the question "Why is this objective

important?" Keeney [14] specified two plausible responses, the first being that the objective describes a core reason for interest in the problem, meaning it is a potential fundamental objective. On the other hand, if the answer to the question brings an additional objective to light it is a potential means objective. This method allows for the development of a value tree or fundamental objective hierarchy, where the fundamental objectives are linked global objectives. Similar to the value tree or fundamental objective hierarchy, the means-ends or objective network aids in identifying fundamental objectives and connecting them to means objectives as well as to the corresponding quantifiable attributes. 
The list of factors identified in the framing phase, Table 1, was used as a basis to construct a set of EP objectives. These objectives are presented in the fundamental objective hierarchy shown in Fig. 2. A disaggregation is made here into economic, social, and environmental fundamental objectives. The shaded boxes represent the level at which attributes were defined. Applicable quantifiable attributes were identified for each of the EP objectives. These are detailed together with methods for their measurement in the refinement phase, Section 4 , which follows.

In the identification of a fundamental objective, the factor "Allows for productive uses of energy" (Table 1) was assumed to be, in essence, the same concern as that expressed in the objective to "Maximize share of population with access to (modern) energy". For this reason it was not added as a separate fundamental objective. Instead, consideration of the productive uses was expressed in the quantifiable attribute used to measure this energy access objective. The quantifiable attributes are described in more detail in Section 4, however the connection between modern energy access and the productive use of energy deserves additional attention. The productive use of energy is inextricably linked to the provision of modern energy. The relation between productive uses of energy and economic development is more readily seen in the standard definition of national energy productivity, or the inverse of energy intensity. The national energy productivity is equal to the ratio of national GDP to national energy consumption (GDP/ktoe). Increased energy productivity results from either increased GDP or decreased energy consumption which can result from increased energy efficiency or shifts in industry or other large energy demands. The direct uses of energy for productivity are then those that bring an increase in GDP, as this can be directly related to income generation. Social and educational uses of energy, long considered unproductive uses, have also been found to be indirectly linked to productivity [17-21]. Modern energy carriers including electricity and LPG are more flexible than traditional fuels providing for a diverse set of FE services. Electricity, for example, can provide instant and relatively effortless access to multiple FE services and provides an unparalleled flexibility, convertible to light, heat, mechanical energy, and chemical potential [22]. Additionally, electricity can be used silently as well as cleanly at the point of use, and with minor adjustments it can be precisely adjusted to provide for desirable speeds and accurate control of particular processes [23]. Flexibility is also related to the adaptability of systems to meet current and future needs, or evolutionary capacity [24].

The factor "Investment costs" (Table 1) was translated into the objective to Minimize the cost (investment, maintenance and operation).

(1.5-column fitting image)

Fig. 2. Fundamental objectives hierarchy: The shaded boxes represent the level where attributes are defined.

\section{Refining the problem}

Following the identification and structuring of the EP objectives, in Sections 2 and 3 respectively, the next phase consisted of the refinement of the decision problem. This comprised detailing the scope of the individual EP objectives and establishing the quantifiable attributes and the methods by which they would be measured. The EP objectives and the corresponding measurable attributes are detailed in the sections which follow.

\subsection{Maximize the security of the PE supply}

Concerns for energy security are, at their root, based on the understanding that the continued functioning of an economy and society requires uninterrupted flows of energy [25]. Energy security can be considered as consisting of long, medium, and short-term considerations. Short-term considerations consist of system operational security while medium-term concerns consist of system generation, or adequacy of capacity to meet FE demand. Medium-term and short-term concerns are addressed in the objective which follows, in Section 4.2, regarding the reliability of the FE system [26]. Long-term considerations consist of ensuring the availability of the PE supply and efforts to hedge against future, possibly unforeseeable interruptions. 
Stirling [27] argued that the most comprehensive strategy to deal with the complete ignorance of future long-term developments was to design for diversity of supply including considerations of variety, balance and disparity. The current work considered the first two of these considerations which are linked to diversity and import dependency concerns.

In terms of attributes to quantify this objective, the Shannon diversity index (also referred to as the Shannon-Weiner or the Shannon-Weaver diversity index), originally developed to measure what is referred to as entropy within the field of information theory by Shannon and Weaver [28], has since been adopted as a measure of diversity and balance in other fields. In the energy sector it has been employed as a measure of diversity of PE supply as a proxy attribute of security of supply. Jansen [29] employed the Shannon index in the development of four attributes of security of supply which progressively build upon a measure of diversity to include additional dimensions. These consisted of diversity, diversity with import dependency, diversity and import dependency with socio-political stability, and finally diversity, import dependency, socio political stability and resource depletion. APERC [30] presented a similar set of five security of supply indicators for diversity, diversity and import dependency, net carbon intensity of the PE supply, net oil import dependency, and Middle East oil import dependency. Löschel et al. [31] adapted the Shannon index to include considerations of indigenous renewable supply in addition to concerns of imported PE supplies. Two of the attributes (diversity and diversity with import dependency) presented by Jansen [29] and APERC [30] allow for measurement of availability, variety and balance in the PE supply. These measures are applicable to the security of supply concerns of diversity and import dependency of the current work. These attributes have previously been employed in the context of PE security in West Africa [32]. The first energy security attribute $\left(E S A_{1}\right)$ provides a measure of diversity of the PE supply as defined in Eq. 1. The second attribute, ESA extends $E S A_{1}$ to also consider the dependency on PE supply imports, as shown in Eq. 2. The second attribute, defined in Eq. 2 , will be used for evaluation of PE supply security in the current work.

$$
\begin{aligned}
E S A_{1} & =D_{1} / D_{\text {max }}=D_{1} / \ln u \quad[-] \\
D_{1} & =-\sum_{r=1}^{U} p_{r} \ln \left(p_{r}\right) \quad[-]
\end{aligned}
$$

Where:

$E S A_{1}$ : The first attribute measuring diversity of PE supply [-]

$D_{1}$ : Shannon-Weiner diversity index ${ }^{2}[-]$

$D_{\text {max }}:$ Maximum possible value of the Shannon-Weiner diversity index [-]

$U$ : Number (count) of primary energy (PE) resources used [-]

$p_{r}$ : Share which PE resource $r$ in total PE supply, for all resources $p=1,2,3, \ldots, \cup[\%]$

$$
\begin{gathered}
E S A_{2}=1-E S A_{\text {import }} / E S A_{1} \\
E S A_{\text {import }}={ }^{D_{2}} / D_{\text {max }}={ }^{D_{2}} / \ln U
\end{gathered}
$$

\footnotetext{
${ }^{2}$ In the calculation of the Shannon-Weiner diversity index where $p_{r}$ the value of the share of PE resource $r$ in total PE supply approaches zero an "intermediate form" is reached in $D_{1}$. L'Hopital's rule is used in this case to evaluate the limit to obtain the final value which in this case is $\lim _{x \rightarrow 0} x \ln (x)=0$.
} 


$$
D_{2}=\sum_{r=1}^{U} c_{r} p_{r} \ln \left(p_{r}\right) \quad \text { Where: } \mathrm{c}_{r}=1-\mathrm{m}_{r} \quad[-]
$$

Where:

$E S A_{2}$ : Measure of PE diversity and import dependency [-]

$E S A_{\text {import }}$ : Import reflective measure of PE diversity [-]

$D_{2}$ : Shannon-Weiner diversity index, import reflective [-]

$D_{\max }:$ Maximum possible value of the Shannon-Weiner diversity index [-]

$U$ : Number (count) of PE resources used [-]

$\mathrm{c}_{r}$ : Correction factor for PE resource $r$, calculated as the share of PE resource $r$ provided by indigenous sources. An increased indigenous PE supply of resource $r$ results in an increased value for $D_{2}[-]$

$p_{r}$ : Share of PE resource $r$ in total PE supply, for all resources in $r=1,2,3 \ldots, \mathrm{U}[\%]$

$\mathrm{m}_{r}$ : Share of net import in PE supply of resource $r$ [\%]

\subsection{Maximize the reliability of FE supply}

Reliability of the FE system refers to the downstream continuity of services supplied or the energy system's ability to meet demand with a consistent and dependable supply of quality energy. ${ }^{3}$ Interruptions in the delivery of FE make for an unreliable energy system. Physical connection or proximity to FE supplies does not ensure that end-users have access to a reliable supply of FE, and therefore the reliability of the FE system is also of concern. For the current work, the electricity generation technologies installed are used as a proxy for the FE system as the provision of a reliable supply of electricity to populations is a priority in the ECOWAS member states [33].

Attributes to quantify reliability of the FE supply consist of short and long-term considerations. The short term is characterized by operational security or quality of the energy supply on the scale of minutes, hours or days, and considerations are typically made through ex-post indicators of unforeseen disturbances. Examples include the system average interruption index, measured as the minutes per customer per year of interruptions, and energy not supplied, measured in units of energy, such as GWh. Evaluation of the reliability of the system at this level requires a model permitting analysis on the order of seconds, minutes and hours, which was out of the scope of the current work, as detailed in Section 1. Long-term considerations consist of measures of adequacy of the FE system to meet demand $[34,26]$. These include electricity generation adequacy measures comparing generation capacities and FE demand [35]. A long(er)-term consideration of reliability is made here of the adequacy of the FE system. The evaluation of generation adequacy from UCTE [34], a long-term measure of reliability was used, as defined in Eq. 3. This long-term evaluation of generation adequacy does not address the short-term unit commitment problem, which is an important consideration for ensuring electrical grid reliability, as this is not within the scale of this analysis. The measure of adequacy employed here does permit the identification of solutions that are a priori compatible with reliable electrical grid operation; however, prior to implementation, it is recommended that any attractive solutions be examined through dynamic, short-time step assessments to ensure electrical grid reliability.

$$
\text { Adequacy }_{y}=100 \times{ }^{R M G C_{y}} / N G C_{y} \quad[-] \quad \text { Eq. } 3
$$

\footnotetext{
${ }^{3}$ Technically, system reliability, different from quality, is the consistent and dependable supply of an energy carrier to the user, while quality for electricity systems refers to a variety of electromagnetic phenomena that characterize the voltage and current at a given time and location and normative descriptions which set acceptable boundaries for these phenomena [26]. Quality considerations could also be made in respect to other carriers, based on criteria specific to those carriers.
} 


$$
\begin{gathered}
R M G C_{y}=R A C_{y}+\text { Import capacity }_{y}-\text { peak load demand } \\
\\
R A C_{y}=N G C_{y}-\text { unavailable capacity }_{y} \quad[M W]
\end{gathered}
$$

Where:

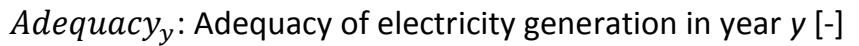

$R M G C_{y}$ : Remaining margin of electricity generation capacity in year $y[\mathrm{MW}]$

$R A C_{y}$ : The remaining generation capacity which results from the difference of the NGC and the unavailable capacity in year $y[\mathrm{MW}]$

$N G C_{y}$ : The net installed generation capacity in the given year [MW]

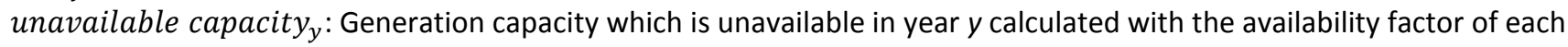
generation capacity technology type [MW]

\subsection{Minimize costs of the energy system}

The energy costs which consumers pay are directly influenced by the costs incurred by utilities in providing energy. This work concentrated on the technical measures which consisted of the costs incurred by the government and or utilities in the investment, operation, and maintenance of energy systems in the implementation of the energy plan. These consisted of transformation technologies (electricity generation), transmission and distribution, and petroleum refining. The scope of this work did not include government or energy utility set profit margins or subsidy programs, as these are context specific promotional mechanisms.

Investment costs include the purchase, delivery and installation costs of technologies. Operation and maintenance costs include fixed and variable costs. The fixed costs consist of the labor expenses, including overheads for operation and maintenance of a system and the operation and maintenance materials, excluding fuels. Fixed costs are typically modeled as a fixed component of currency per year, or for power systems as currency per unit power per year [36]. In addition to fixed costs there are variable costs which include fuel costs. Variable costs can be measured in terms of output, as cost per unit of electricity generated, or alternatively as a fixed operation and maintenance cost per year per unit of capacity [37].

The natural attribute of costs was selected for this work, in order to measure the achievement of the objective by alternatives, and was divided into two components (1) the investment costs and (2) operation and maintenance costs. Costs were evaluated as the total of all applicable costs from electricity generation capacity for national grid, minigrid and standalone systems. The costs for transmission and distribution line extensions were considered as well as the costs for additional petroleum refinery capacity. Total costs in year y, as shown in Eq. 4, are calculated as the sum of the respective costs for each of these considerations (i.e. electricity generation, transmission and distribution, electricity connections, and petroleum refineries). The investment, operation and maintenance and the electricity generation fuel costs for electricity are obtained according to Eq. 5, Eq. 6, and Eq. 7.

$$
\text { Total Cost } \text { To }_{h=1}^{Q} \operatorname{Cost}_{h, y} \quad[\text { Monetary Units }]
$$

Where:

Total Cost $y$ : Total costs from all cost sectors considered, for $h(1=$ electricity generation capacity, $2=$ transmission and distribution system, $3=$ new connections (access), and $4=$ petroleum refineries) in year $y$ [Monetary units] $\operatorname{Cost}_{h, y}$ : Total annual cost from sectors considered for $h(1=$ electricity generation capacity, $2=$ transmission and distribution system, $3=$ new connections (access), and 4= petroleum refineries), in year $y$ [Monetary units] 


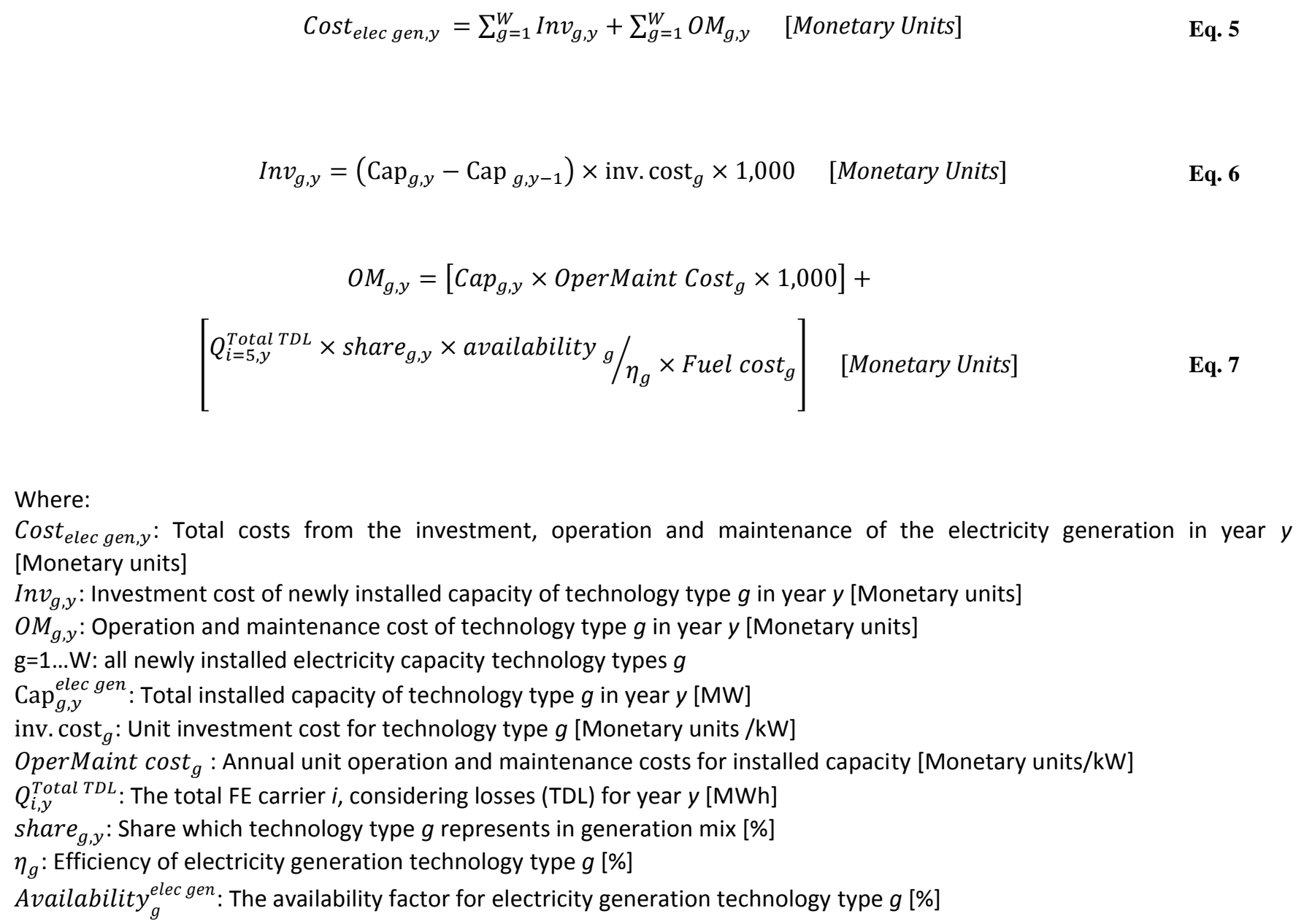

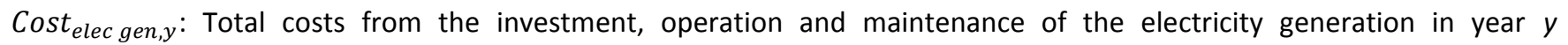

Inv $v_{g, y}$ : Investment cost of newly installed capacity of technology type $g$ in year $y$ [Monetary units]

$O M_{g, y}$ : Operation and maintenance cost of technology type $g$ in year $y$ [Monetary units]

OperMaint cost $_{g}$ : Annual unit operation and maintenance costs for installed capacity [Monetary units/kW]

Availability ${ }_{g}^{\text {elec gen }}$ : The availability factor for electricity generation technology type $g$ [\%]

Where: [Monetary units]

$\mathrm{g}=1 . . \mathrm{W}$ : all newly installed electricity capacity technology types $g$

$\mathrm{Cap}_{g, y}^{\text {elec gen }}$ : Total installed capacity of technology type $g$ in year $y[\mathrm{MW}]$

inv. cost $_{g}$ : Unit investment cost for technology type $g$ [Monetary units $/ \mathrm{kW}$ ]

$Q_{i, y}^{\text {Total TDL }}$ : The total FE carrier $i$, considering losses (TDL) for year $y$ [MWh]

share $_{g, y}$ : Share which technology type $g$ represents in generation mix [\%]

$\eta_{g}$ : Efficiency of electricity generation technology type $g$ [\%]

Fuel cost $t_{g}$ : Cost of fuel which corresponds to technology type $g$ [Monetary units/ktoe]

Calculation of costs for transmission and distribution line investments followed the work by Rosnes and Vennemo [38] for SSA which based growth of stock on energy demands. The annual investment costs for transmission and distribution, Eq. 9, were based on the growth of FE demand for electricity from year $y-1, Q_{i, y-1}^{\text {Total } T D L}$, to year $\mathrm{y}$, an assumption of the growth rate, Growth ${ }_{b}$, in relation to this demand growth and currently installed stock, Stock $k_{b, y-1}$, and a unit investment cost, inv. $\operatorname{cost}_{b}$. Operation and maintenance costs were based on the value of the total installed stock in the year $y$, value of stock , and assumed operation and maintenance costs, OperMaint cost $_{b}$, per unit of total installed stock. The calculation of transmission and distribution costs was completed following Eq. 8 to Eq. 10.

$$
\begin{gathered}
\text { Cost }_{h, y}=\sum_{b=1}^{Z} \text { Investment }_{b y}+\sum_{b=1}^{Z} \text { OM }_{b, y} \quad[\text { Monetary Units }] \\
\text { Investment }_{b, y}=Q_{i, y}^{\text {Total TDL }}-Q_{i, y-1}^{\text {Total TDL }} / Q_{i, y-1}^{\text {Total TDL }} \times \text { Growth }_{b} \times \text { Stock }_{b, y-1} \times{\text { inv. } \text { cost }_{b}}
\end{gathered}
$$




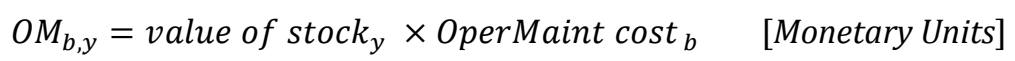

Where:

$Q_{i, y}^{\text {Total TDL }}$ : The total demand of FE carrier i, considering transmission and distribution losses (TDL) for year $y$ [ktoe]

$O M_{b, y}$ : Total operation and maintenance cost for line type $b$, in year $y$ [Monetary Units]

Investment $_{b y}$ : Total operation and maintenance cost for line type $b$, in year $y$ [Monetary Units]

Growth $_{b}$ : Growth rate of line type $b$ where $b=1$ is transmission and $b=2$ is distribution [\%]

Stock $k_{b, y-1}$ : Total stock in distance of line type $b$ in year $\mathrm{y}-1[\mathrm{~km}]$

inv. $\operatorname{cost}_{b}$ : The unit investment cost of line type $b$ [Monetary units $/ \mathrm{km}$ ]

value of stock: Total value of existing stock, compounded from base year, [Monetary units]

OperMaint $\operatorname{cost}_{b}$ : The operation and maintenance cost as a share of the total value of existing stock of line type $b$ [\%]

The costs for new connections, or energy access, were based on the population type $p(1=$ CoreUrban, $2=$ PeriUrban, $3=$ Rural) and the connection type $c(1=$ national grid - Urban, $2=$ national grid - Rural, $3=$ minigrid - Rural and $4=$ standalone systems - Rural) in the year $y$, as shown in Eq. 11.

$$
\text { Cost }_{h, y}=\sum_{p=1}^{3} \sum_{c=1}^{4} \text { Connections }_{p, y} \times \text { Share }_{c, y} \times \text { Connect Cost }_{c} \quad[\text { Monetary Units }] \quad \text { Eq. } 11
$$

Where:

Connections $_{p, c}$ : Number of households newly connected in year $y$ [households]

Share $_{c, y}$ : Share of new connections met by connection type $c$ in the year $y[\%]$

Connect Cost $_{c}$ : Cost per new connection of type $c$ [Monetary units / household]

The oil refinery costs were based on specific costs for newly installed capacity interventions over the planning horizon, presented in Eq. 12.

$$
\text { Cost }_{h, y}=\text { Investment }_{\text {capacity }, y} \quad[\text { Monetary Units }] \quad \text { Eq. } 12
$$

Where:

$\operatorname{Cost}_{h, y}$ : Costs for specific investments in oil refinement capacity [Monetary units]

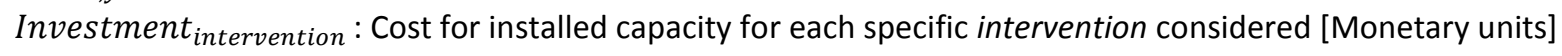

Energy system projects are capital intensive, requiring significant monetary investments. These are typically financed in the form of a loan in which the cost is spread over a certain number of years, in addition to annual interest. The annual investment costs for a project required to accumulate to a given present investment with a given interest rate, $i$, and number of years, $N$, was calculated by the familiar uniform capital recovery formula [39]. The annual investment costs for the current work were calculated following this uniform capital recovery formula. The operation and maintenance costs were considered to be paid in full annually. 


\subsection{Maximize the maintainability of the FE system}

The maintainability of the FE system refers to the ability of the system to function with minimal difficulties for normal maintenance and unscheduled repairs. The maintainability of the energy system within this work consists of three components, namely the (1) proveness of the technology in the West African context, (2) availability of parts and maintenance, and (3) local capacity for installation operation and maintenance.

In the absence of a comprehensive natural or proxy attribute for the maintainability of the FE system, a constructed scale attribute with four defined levels was developed. The attribute evaluates the maintainability of the electricity generation system as a proxy of the FE system, as the provision of electricity to populations is an important concern in developing countries, and specifically in the ECOWAS region. The maintainability was defined by three criteria within each level; proveness of the technology in the West African and African context, availability of parts and maintenance, and local capacity for installation operation and maintenance. The defined levels are presented in Table 2, and here it is seen that lower values on the scale are more desirable (more maintainable) than higher ones.

The measurement of maintainability consists of a weighted sum, where the maintainability is equal to the product of the weights of each technology in the electricity generation scheme, $w$, and their evaluated level of maintainability, $L$, as indicated in Eq. 13.

$$
\begin{gathered}
\text { Maintainability }=\sum_{u=1}^{Y} w_{u, y} \times L_{u}^{M} \quad[-] \quad \text { Eq. } 13 \\
\sum_{u} w_{u}=1 \text { and } 0 \leq w_{u} \leq 1 \text { for all } u=1 \ldots Y
\end{gathered}
$$

Where:

$w_{u, y}$ : Share which the technology represents in the total installed capacity of electricity generation technologies in year $y$ for all installed capacity generation technologies $u=1,2,3, \ldots, Y$ in year $y[-]$

$L_{u}^{M}$ : The evaluated level of maintainability $(M)$ of the installed generation technology type $u[-]$

There are limitations to the approach used here. The constructed scale of maintainability is a qualitative scale, but performing a weighted sum requires assuming that the difference from 0 to 1 is equal to the difference from 1 to 2 and etc. Therefore, care was taken to explicitly define each level 0, 1, 2 and 3 ensuring that each would represent similar value differences. For the evaluation of maintainability of generation technologies, each generic generation type was assigned a maintainability level, based on information available and expert evaluation. In future cases, in which specific generation technologies are to be considered within a planning activity, each specific generation plant can be evaluated separately for maintainability by the analysts and DMs involved. It is acknowledged that assigning defined levels to the technologies may be subjective to the DMs and their expertise; however this could be done within a conference environment allowing for discussion and compromise. As an example, the generic technology maintainability levels assigned for a case study of Ghana are presented in Table B 1 of Appendix B.

Table 2. Defined levels of constructed scale of maintainability

\subsection{Maximize access to the FE supply}

There is no consensus on how to define and measure FE access. Multiple definitions exist and are established according to the purpose of the measurement or the data available [40-42]. Definitions include physical connections to energy supplies (in the case of electricity), ability to connect or use FE carriers, physical proximity or the offer, and energy poverty 
considerations (which has multiple definitions) [42,43]. Despite having access to energy, the affordability of energy is a limiting factor often discussed together with energy access [44]. In this work the affordability of the energy supply is considered to be influenced through the objective of minimizing costs, as the costs of the energy infrastructure and supply system affect the end-use energy prices, discussed in Section 4.3, with the objective to Minimize costs of the energy system.

Energy access in the context of the current work refers to access to modern energy carriers such as electricity and gas which provide for modern energy services (e.g., gas cooking, electric lighting, etc.) at the household level. This is opposed to access to traditional energy carriers such as biomass. The measure of access to a particular carrier (e.g., electricity) is biased to one carrier and leaves little room for choice by the end-user, whose demand for energy may vary. An alternative to the measure of access to energy, a supply side perspective, is the measure of deprivation of energy services, a perspective in line with a demand side approach. Measuring the deprivation of energy services allows for quantification of demand for energy services and permits the demands to be met by energy carriers which are the most suited for the specific context. This approach requires the identification of novel indicators and/or attributes; however, it can also be expressed from an inverted definition, as the provision of FE services [45].

A constructed attribute was developed to measure access which populations, with specific energy carrier portfolios, have to modern FE services. Ten representative household energy carrier portfolios were identified. These were combinations of energy carriers which households may have access to in a given year. Each portfolio was evaluated in respect to the number of FE services which could be provided with each portfolio as shown in Table 3. All FE carrier portfolios, whether stated or not, include access to fuelwood. Here it is seen that access to electricity is assumed to provide for a greater number of FE services than portfolios without electricity access such as the fuelwood only portfolio. The measurement of access to energy was completed as indicated in Eq. 14. It is acknowledged that this approach assumes that all the FE services considered are of equal importance, which may not be the case. This assumption should of course be discussed with DMs in applications to ensure that the approach is tailored to their needs.

$$
\operatorname{Access}_{y}=\sum_{p=1}^{3} \sum_{m=1}^{S} \text { Share }_{p, m, y} \times H H S_{p, y} \times \text { Services }_{m} / \sum_{p=1}^{3} H H S_{p, y} \quad[-] \quad \text { Eq. } 14
$$

Where:

Access $_{y}$ : Constructed value evaluating access in year $y$ to FE services which lies on the range of 0 to 12 as 12 energy services are assumed [-]

Share $_{p, m, y}$ : Percentage of households in population type $p$ with access to portfolio $m$ in year $y$ [\%]

$H H S_{p, y}$ : Number of households of population type $p$ in year $y$ [count]

Services $_{m}$ : FE services assumed available to households with access to portfolio $m$ [count of FE services]

Table 3. Energy carrier portfolios and respective FE services provided in current work

\subsection{Minimize impact of the energy system on the global climate}

The GHG emissions from fossil fuel combustion have been identified as the largest share of anthropogenic contribution to global GHG emissions. The reliance on fossil fuels has resulted in increased GHG emissions globally, and the energy sector is typically responsible for over $90 \%$ of $\mathrm{CO}_{2}$ and $70 \%$ of all $\mathrm{GHG}$ emissions in developed countries [46]. The attribute of $\mathrm{CO}_{2}$ equivalent emissions $\left(\mathrm{CO}_{2 \text { eq }}\right.$ ) is a commonly used proxy attribute of the energy system's influence on global climate [7]. The guidelines for national inventories of GHG emissions from the Intergovernmental Panel on Climate Change (IPCC) [46] provide a standardized procedure for calculation of energy sector emissions.

The IPCC guidelines provide three separate tiers for accounting. Each tier represents a progressively more detailed approach for the accounting of emissions from sources based on default emissions factors, national or regional factors, and 
activity or technology specific data for each tier [46]. Tier 1 of the IPCC guidelines were sufficient for the evaluation for all of the emission sources considered for the case study country in this work.

The current work followed the IPCC [47] using the established 100 year Global Warming Potentials. The sum of these equivalent $\mathrm{CO}_{2 \text { eq }}$ emissions was calculated for the mix of $\mathrm{GHG}$ emissions considered (i.e. $\mathrm{CO}_{2}, \mathrm{CH}_{4}$, and $\mathrm{N}_{2} \mathrm{O}$ ) to find the total $\mathrm{CO}_{2 \text { eq, }}$, here referred to as Total GHG. The $\mathrm{CO}_{2 \text { eq }}$ can be calculated by the multiplication of GHG emissions by the associated global warming potential, as shown in Eq. 15. The annual GHG emissions were calculated as the total emissions from the separate sources considered following Eq. 16. The emissions from mobile sources, for tier 1 considerations, were calculated based on the fuel combusted in the individual subsectors and transport types considered as in Eq. 18.

$$
\text { Total } G H G_{y}=\sum_{f=1}^{N} G H G_{f, y} \times G W P_{f} \quad[k t o n] \quad \text { Eq. } 15
$$

Where:

Total $\mathrm{GHG}_{y}$ : The total $\mathrm{CO}_{2 \text { eq }}$ in year y [kton]

$G H G_{f, y}$ : The total emissions of GHG $f$, for GHG $f=1 \ldots \mathrm{N}$, in year $y$ [kton]

$G W P_{f}$ : Global Warming Potential of GHG $f[-]$

$$
G H G_{f, y}=\sum_{d=1}^{R} G H G_{f, d, y} \quad[k t o n / y e a r]
$$

Where:

$G H G_{f, d, y}$ : Total emissions of GHG $f=1 \ldots \mathrm{N}$ from emission source sector $d$, in year y [kton/year]

$d=1,2,3, \ldots, \mathrm{R}$ : Emission source sectors, electricity generation, petroleum refining, and transportation

The current work considers energy sector GHG emissions arising from three emission sources at the national level, namely stationary combustion for production of electricity, mobile combustion for transportation, and refinement of crude oil. The measurement of GHG emissions from stationary combustion from electricity generation and petroleum refining sources followed Eq. 17.

$$
G H G_{f, d, y}=\sum_{r=1}^{U} P E S_{r, d, y} \times \text { emission } \text { factor }_{f, r} \times \text { unit conversion }_{r} \quad[k \text { ton/year }]
$$

Eq. 17

Where:

$G H G_{f, d, y}$ : Total emissions of GHG $f=1 \ldots \mathrm{N}$ from emission source sector $d$, in year $y$ [kton/year]

$P E S_{r, d, y}$ : PE supply, $r$ combusted in emission source sector $d$, in year $y$ [ktoe]

emission factor $_{f, r}$ : Default emission factor of GHG $f$ for PE supply $r[\mathrm{~kg} / \mathrm{TJ}]$

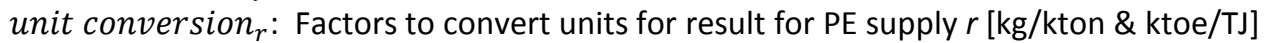

$d=1,2,3, \ldots, \mathrm{R}$ : Emission source sectors, electricity generation, petroleum refining, and transportation $r=1,2,3, \ldots$, U: PE supply (e.g., natural gas, coal, and residual fuel oil)

$$
G H G_{f, d, y}=\sum_{k=1}^{O} \sum_{s=1}^{P} \sum_{i=1}^{M} Q_{k, s, i, y} \times \text { emission }_{\text {factor }_{f, r}} \times \text { unit conversion }_{r} \quad[k \text { ton } / \text { year }] \quad \text { Eq. } 18
$$

Where:

$G H G_{f, d, y}$ : Total emissions of GHG $f=1 \ldots \mathrm{N}$ from emission source sector $d$, in year $y$ [kton/year]

$Q_{k, s, i, y}$ : FE demand for FE carrier $i$ for transport type $s$ in transport subsector $k$ in year $y$ [ktoe]

emission factor $_{f, r}$ : Default emission factor for PE supply $r[\mathrm{~kg} / \mathrm{TJ}]$

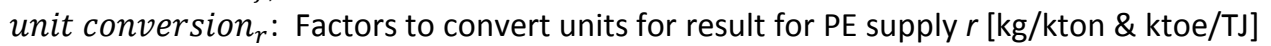

$k=1,2,3, \ldots$, O: Transport sectors (e.g., Passenger-Road, Freight -Rail, and Passenger-Domestic Air) 
$s=1,2,3, \ldots$, P: Transport types (e.g., Passenger-Private- Automobiles, Passenger-Collective- Taxi, and Freight-RailLocomotive)

$i=1,2,3, \ldots, \mathrm{M}$ : FE carriers (e.g., Diesel, LPG, and aviation turbine kerosene)

\subsection{Minimize impact of the energy system on the local environment}

The potential impacts which the national energy system may have on the local environment are numerous, as are the metrics which can be employed to measure them. These impacts result from the exploration of, generation, delivery, and utilization of energy in its many forms (i.e. PE resources and FE carriers). For the current work the environmental impacts on the local environment consisted of those resulting from the installation and use of electricity generation technologies as a proxy of the FE system. The dimensions considered here for local environmental impact included the impact on air, water and land quality. Impacts on the local environmental result from the release of air, water and solid waste pollutants (other pollutants not considered in this work also exist and include noise and light). These pollutants can impact different dimensions of the local environment; however, specific pollutants are typically used as proxy measures for impacts on specific dimensions of the local environment due to their predominant impact.

In the absence of a comprehensive natural or proxy attribute which evaluates all of the impacts of concern, a constructed scale attribute with four defined levels was developed. The attribute evaluates the local environmental impact of the electricity generation system as a proxy of the FE system. The current model was not constructed to conduct a detailed evaluation of environmental impacts, but to allow for the comparison of relative environmental impacts between multiple alternatives. A constructed attribute allowing for evaluation along multiple dimensions of local environmental impacts is suitable for this. Each level is defined by an appropriate description of local environmental impact. The impact is defined by three criteria at each level; air quality, water quality, and land quality for installation operation and maintenance of electricity generation technologies. These criteria have the same role so that evaluation of the impact on one criterion (e.g., land) may decide the attribute level evaluated despite no or negligible impacts in the remaining criteria. The defined levels are presented in Table 4, and it is seen that lower values on the scale are more desirable than higher ones. The installed capacity $[\mathrm{MW}$ ] was considered to be a reasonable proxy for the measure of the impact on the local environmental impact on air, land and water quality which an electricity generation technology has.

A weighted sum aggregation was used where the local environmental impact is equal to the product of the weights of each technology in the electricity generation scheme, $w$, and their evaluated level of impact, $L$, as shown in Eq. 19. It is acknowledged that the weighted sum is an approximation as it considers the installed generation technology and not the capacity actually used, and the former may be larger than the latter. Since performing a weighted sum assumes the difference from 0 to 1 is equal to the difference from 1 to 2 and etc., care was taken to explicitly define each level 0 , 1,2 and 3 ensuring that each would represent similar value differences. The defined levels may be discussed with DMs in further applications to ensure their suitability.

$$
\begin{gathered}
\text { Local Env. Impact } \text { Imp }_{u=1}^{W} w_{u, y} \times L_{u}^{E} \\
\sum_{u} w_{u}=1 \text { and } 0 \leq w_{u} \leq 1 \text { for all } u=1,2,3, \ldots Y
\end{gathered}
$$

Where:

$w_{u, y}$ : Share which the technology represented in the total installed capacity of electricity generation technologies in year $y$ for all installed capacity generation technologies $u=1,2,3, \ldots, Y[\%]$

$L_{u}^{E}$ : Evaluated level of local environmental impact $(E)$ of the generation technology type [-] 
Table 4. Defined levels of constructed scale of impact on local environment

The impact on air quality was established based on assumed emission of air pollutants of concern, namely the commonly employed metrics of $\mathrm{NO}_{2}, \mathrm{SO}_{x}$ and particulate matter [48-53]. The water quality impact was evaluated based on the assumed withdrawal of water, the consumption of water, and affluent discharge in to natural water ways [51,54-56,52]. The land quality impact was evaluated based on deforestation, transformation of land, and the length of occupation $[51,57,58,52,59,60]$. Each generic generation type was assigned a local environmental impact level, based on information available on the generation type and expert evaluation. In future cases in which specific generation technologies are to be considered within a planning activity, each specific generation plant could be evaluated separately by the DMs involved. It is acknowledged here that assigning defined levels to the technologies may be subjective to the DM and their preferences; however this could be done within a conference environment allowing for discussion and compromise. As an example, the generic technology local environmental impact levels for a case study of Ghana are presented in Table B 2 of Appendix B.

\section{Case study of Ghana}

The EP objective set and corresponding measurable attributes identified in this work were applied to a case study of the country of Ghana, an ECOWAS member state, to illustrate their use in the evaluation of a reference "business as usual" projection. A forecast or projection, as used in this work, is that which provides information about possible future situations, which in this case consist of the national FE demand and PE supply along the planning horizon [61]. The Reference Projection was made to evaluate the performances on the attributes within a "business as usual" future. This Reference Projection was made within the considerations of a future scenario. Scenarios consist of the conditions which are outside the scope of the modeler, but which are relevant to the future situations (e.g., GDP and population projections) [61]. Following these definitions, a reference projection, of FE demand and PE supply, is made within the constraints set by the scenario along the planning horizon.

The most recent, and first, national EP activity conducted by the Energy Commission of Ghana was the Strategic National Energy Plan (SNEP) for Ghana, completed in 2006 [62]. The SNEP provided a strategic medium term plan, with a planning horizon from 2006-2020, for the provision of energy to support development. In order to have results which were comparable to the SNEP, it served as the primary source of data of this case study. A medium-term planning horizon from 2008 to 2020 was used. $^{4}$

\subsection{Energy Modeling}

A national energy system projection model was developed and applied to the Case study of Ghana. One of the outputs of the model, beyond FE demand and PE supply projections, was the data necessary as inputs for the measurable attributes defined previously in Section 4. The current work does not go into detail on the energy model-considered outside the scope of the current work; however, key assumptions for a reference projection are presented. Detailed descriptions of the model are presented in Lee [8].

To establish a scenario, key assumptions were required as inputs for the energy demand and supply model. In order to have results that represented a Reference Projection and that were comparable with those of the SNEP, these key assumptions followed those cited in the SNEP, energy statistics from the Energy Commission of Ghana, or data from SSA as adequate proxies. The current work followed the High Economic Growth scenario detailed in the SNEP in which GDP was forecast to grow from 19.5 billion in 2008 to 60 billion United States dollars (US \$) in 2020. This corresponds to a growth in GDP per capita from approximately 896 to 1,809 US $\$$ per capita in the same time horizon. It is of note here that Ghana exceeded the expectations in the forecasted GDP in the SNEP and reached 1,841 US \$/capita in 2013; however the SNEP values were

\footnotetext{
${ }^{4}$ Although the base year of the SNEP was 2006, the most detailed data was available for the year 2008 and so this was used in the current work as the base year. Comparison of what was referred to as the base year for the current work was in-turn done for this year 2008.
} 
used to allow for comparison with the modeling results [63]. The population was forecast to grow to 33.2 million by 2020 from 21.8 million in 2008. By the end of the planning horizon the largest share of this population resides in rural areas; however the share of urban population grows from $40 \%$ to $48 \%$ by 2020 [64].

Assumptions on the level of access to energy, for each of the FE carriers considered, within the CoreUrban, PeriUrban and Rural population types were required for the Residential sector. Access to electricity was assumed to reach $100 \%$ by 2020 following the SNEP. Extension of the national grid was the preferred route for efforts to increase access to electricity for Rural households in the Reference Projection. For new Rural household access connections, $80 \%$ of connections were to the national grid and the remaining $20 \%$ were evenly divided between minigrid and standalone connections. New connections within CoreUrban and PeriUrban areas were assumed to be $100 \%$ national grid connections as all cities have been connected. These assumptions follow previous efforts in Ghana and SSA that have given preference to national grid access $[38,64]$.

\subsection{Evaluation}

The set of measurable attributes, established in Section 4, were used to evaluate the Reference Projection in achievement of the EP objectives. Additional data requirements for the measurement of the attributes for the case study of Ghana are presented in Appendix B (Supplementary material). Additional data used as inputs to the attribute of cost (See Section 4.3) represents data for the country of Ghana; however, where this was unavailable, data from SSA was used a proxy. Tier 1 default emissions factors were used as inputs for the attribute on global climate as discussed in Section 4.6.

The performance of the Reference Projection is presented in Table 5. The performances shown in Table 5 illustrate the use of the established EP objectives and corresponding attributes in the evaluation of the Reference "business as usual" Projection. The evaluation of the Reference Projection is valuable as it provides insight into EP considerations including cost, access to modern energy services, and the impact on the global climate. This information, however, is perhaps most valuable as a base of comparison with constructed alternatives and is to be presented in future work. These alternatives consist of sets of actions (e.g., policies) constructed by the modeler, which result in futures reflecting different outcomes as compared to a reference projection [61]. With a set of EP alternatives DMs can evaluate the performance of alternatives in the achievement of established EP objectives as opposed to a reference "business as usual" projection.

Attribute 2 measuring the cost for the investment, operation, and maintenance attributed to energy sector activities for the Reference Projection is seen to reach 86.0 billion US $\$$ in Table 5. The access to modern energy services, Attribute 5 in Table 5 , reaches a level of 12.00 , indicating that $100 \%$ of the population has access as described in measurable attribute, Section 4.5, and the assumptions for the Reference Projections, Section 5.1. The impact on the global climate, Attribute 6 in Table 5 , is shown to reach a value of $296 \mathrm{Mton}^{\mathrm{CO}_{2 e q}}$ by 2020. This corresponds to emissions of $8.9 \mathrm{CO}_{2 \text { eq }} /$ capita in Ghana for the Reference Projection. ${ }^{5}$

Table 5. Evaluation of the Reference Projection: Case study of Ghana

\section{Discussion}

The purpose of this work was to identify a set of EP objectives and quantifiable attributes which were specific to the context of application (i.e. the ECOWAS region) and which may support successful implementation and sustainability of energy sector plans and projects. Two EP objectives specific to the context of the ECOWAS were identified. These two objectives were to: (1) Maximize the maintainability of the FE supply system, and (2) Maximize the access to FE (modern energy) services. These two specific additional EP objectives were included in a set of seven EP objectives for EP in the ECOWAS

\footnotetext{
${ }^{5}$ The GHG emissions per capita were calculated with the performance of the Reference Projection on the EP objective to Minimize Impact of Energy System on Global Climate (Table 5), and the projection of population growth, Section 5.
} 
region comprising; (3) Maximize PE security, (4) Maximize the reliability of the FE system, (5) Minimize the costs (investment, operation \& maintenance), (6) Minimize the influence of the energy system on the global climate, and (7) Minimize the impact of the energy system on the local environment (See the EP objective set discussed in Section 3). Excluding the two context specific objectives (i.e., maintainability and energy access), the objectives identified in this work align closely with the "three $E$ " themes of energy security, economic development, and environmental protection common to EP activities of developed countries [5-7].

Quantifiable attributes were identified and/or constructed allowing for the two ECOWAS context specific EP objectives to become operational within the EP structure. A constructed scale attribute was developed to evaluate (1) the maintainability of the FE supply system (Described in Section 4.4). A constructed attribute was also developed to evaluate (2) the level of access which the population has to FE services within the EP alternatives (Detailed in Section 4.5). Quantifiable attributes were also identified and/or constructed for the remaining EP objectives. The quantifiable attributes, corresponding to the EP objectives identified above, consisted of attributes of: (3) PE diversity and import dependency, (4) Adequacy of electricity generation, (5) Cost in monetary units of total investment, operation and maintenance of energy system, (6) $\mathrm{CO}_{2}$ emissions, and a (7) Constructed scale of local environmental impact of the FE system (Detailed in Section 4).

The set of EP objectives and quantifiable attributes were employed in a case study of the country of Ghana providing an illustration of their use in the evaluation of a Reference "business as usual" Projection. Future work will include the construction of multiple EP alternatives, representing policy actions, and evaluation of these alternatives in achievement of the EP objectives. The constructed alternatives could then be evaluated and compared against the Reference Projection, presented in the current work, in their achievement of the EP objectives.

Adequate EP methodologies are required in the development and successful implementation of energy policies. Ensuring that EP begins with the bottom-up development of context specific objectives that align with energy policies aids in avoiding ad-hoc decision making. Use of the context specific EP objective set, and/or the problem structuring method presented in the current work, within an EP methodology may support implementation and sustainability of national EP activities in the countries of the region. An applicable EP methodology would be one which supports the construction of multiple EP alternatives, representing policy actions, and the systematic evaluation of these alternatives in achievement of the EP objectives, within a structured multicriteria evaluation framework. A methodology of this description may support future EP activities as it would be a structured and transparent method to develop and evaluate EP alternatives in achievement of stated EP objectives.

It is important to note that the objectives identified through the methodology followed in this work were developed in the scope of developing countries and national EP activities in the ECOWAS region. Neither the methodology nor the EP objectives and corresponding attributes identified are immediately applicable to EP activities in other regions and/or countries.

\section{Acknowledgements}

The authors would like to express their deep gratitude to The Energy Center at Kwame Nkrumah University of Science and Technology (KNUST) in Kumasi, Ghana, and in particular Professor Ahmad Addo, Professor Imoro Braimah, and Gifty Mensah for their support in hosting and facilitating a research visit, providing the necessary data, and verifying assumptions. The authors are particularly thankful to Dr. Joseph Essandoh-Yeddu and the Strategic Planning and Policy team with The Energy Commission of Ghana who were invaluable in facilitating this research, providing data, and verifying assumptions.

Funding: This work was developed under the financial support of the Portuguese Foundation for Science and Technology in the frame of the MIT Portugal Program, through scholarship (SFRH/BD/51585/2011). The work was partially developed with the financial support of a scholarship provided by the Faculty of Engineering, University of Porto (FEUP). 


\section{References}

[1] UN-Energy, Energy for sustainable development: Policy options for Africa. Chapter 6: Fostering medium and long-term energy planning and prospects for nuclear energy in Africa, United NationsEnergy/Africa, New York, NY, 2007. https://www.iaea.org/OurWork/ST/NE/Pess/publications.html.

[2] ESD, ECl, CEEEZ, ESD Africa, PDG, Energy Planning in Developing Countries - facing the challenges of equitable access, secure supply and climate change., Energy for Sustainable Development Ltd (ESD), Environmental Change Institute, University of Oxford (ECI), Centre for Energy Environment and Engineering (Z) Ltd (CEEEZ), Energy for Sustainable Development Africa (ESD Africa), and Palmer Development Group (PDG) for Department of International Development DFID, Corsham, United Kingdom, 2007. http://r4d.dfid.gov.uk/Project/60512/ (accessed June 15, 2015).

[3] ECREEE, ECOWAS renewable energy policy (EREP), Centre for Renewable Energy and Energy Efficiency (ECREEE), Praia, 2012.

[4] F. Kemausuor, G.Y. Obeng, A. Brew-Hammond, A. Duker, A review of trends, policies and plans for increasing energy access in Ghana, Renewable and Sustainable Energy Reviews. 15 (2011) 5143-5154. doi:10.1016/j.rser.2011.07.041.

[5] N.C. Lee, V.M.S. Leal, A review of energy planning practices of members of the Economic Community of West African States, Renewable and Sustainable Energy Reviews. 31 (2014) 202-220. doi:10.1016/j.rser.2013.11.044.

[6] J. Logan, T.L. James, A comparative review of a dozen national energy plans: Focus on renewable and efficient energy, National Renewable Energy Laboratory (NREL), Golden, CO, 2009. https://www.nrel.gov/docs/fy09osti/45046.pdf (accessed September 10, 2017).

[7] G. Haydt, V. Leal, L. Dias, Uncovering the multiple objectives behind national energy efficiency planning, Energy Policy. 54 (2013) 230-239. doi:10.1016/j.enpol.2012.11.027.

[8] N.C. Lee, Decision support methodology for national energy planning in developing countries: An implementation focused approach, Ph.D. Thesis, Faculty of Engineering, University of Porto, 2016. http://hdl.handle.net/10216/85506 (accessed April 30, 2017).

[9] C. Bouvy, C. Kausch, M. Preuss, F. Henrich, On the Potential of Multi-objective Optimization in the Design of Sustainable Energy Systems, in: M. Ehrgott, B. Naujoks, T.J. Stewart, J. Wallenius (Eds.), Multiple Criteria Decision Making for Sustainable Energy and Transportation Systems, Springer Berlin Heidelberg, 2010: pp. 3-12. http://dx.doi.org/10.1007/978-3-642-04045-0_1.

[10] J. Rosenhead, Past, present and future of problem structuring methods, J Oper Res Soc. 57 (2006) 759-765.

[11] F. Ackermann, Problem structuring methods "in the Dock": Arguing the case for Soft OR, European Journal of Operational Research. 219 (2012) 652-658. doi:10.1016/j.ejor.2011.11.014.

[12] L.P. Neves, L.C. Dias, C.H. Antunes, A.G. Martins, Structuring an MCDA model using SSM: A case study in energy efficiency, European Journal of Operational Research. 199 (2009) 834-845. doi:10.1016/j.ejor.2009.01.053.

[13] A.R. Neves, V. Leal, J.C. Lourenço, A methodology for sustainable and inclusive local energy planning, Sustainable Cities and Society. 17 (2015) 110-121. doi:10.1016/j.scs.2015.04.005.

[14] R.L. Keeney, Value-focused thinking: A path to creative decision making, Harvard University Press, Cambridge, 1992.

[15] C.H. Antunes, L. Dias, G. Dantas, J. Mathias, L. Zamboni, An Application of Soft Systems Methodology in the Evaluation of Policies and Incentive Actions to Promote Technological Innovations in the Electricity Sector, Energy Procedia. 106 (2016) 258-278. doi:10.1016/j.egypro.2016.12.121.

[16] D. von Winterfeldt, B. Fasolo, Structuring decision problems: A case study and reflections for practitioners, European Journal of Operational Research. 199 (2009) 857-866. doi:10.1016/j.ejor.2009.01.063.

[17] V. Modi, Energy services for the poor, Earth Institute and Department of Mechanical Engineering, Columbia University, New York, 2001.

[18] R.D. White, GEF/FAO workshop on productive uses of renewable energy: Experience, strategies, and project development, Workshop June 18-20, 2002, Rome, 2002.

[19] K. Kamal, Productive uses of renewable energy: A Review of four Bank-GEF Projects, World Bank, Washington, D.C., 2004. 
[20] GNESD, Reaching the Millennium Development Goals and beyond, access to modern forms of energy as a prerequisite, Global Network on Energy for Sustainable Development (GNESD), Copenhagen, 2007.

[21] C. de Gouvello, L. Durix, Maximizing the productive uses of electricity to increase the impact of rural electrification programs, Energy Services Management Program, The World Bank, Washington, DC, 2008.

[22] V. Smil, Energy at the crossroads: Global perspectives and uncertainties, MIT Press, London, 2005.

[23] S.H. Schurr, Energy use, Technological Change, and Productive Efficiency: An Economic-Historical Interpretation, Annu. Rev. Energy. 9 (1984) 409-425. doi:10.1146/annurev.eg.09.110184.002205.

[24] R.C. Wicklein, Designing for appropriate technology in developing countries, Technology in Society. 20 (1998) 371-375.

[25] B. Kruyt, D.P. van Vuuren, H.J.M. de Vries, H. Groenenberg, Indicators for energy security, Energy Policy. 37 (2009) 2166-2181. doi:10.1016/j.enpol.2009.02.006.

[26] REKK, Measures and indicators of regional electricity and gas supply security in central and south-east Europe, Regional Centre for Energy Policy Research: Corvinus University of Budapest, Budapest, 2009.

[27] A. Stirling, On the economics and analysis of diversity, Science Policy Research Unit. Centre for the Study of Evolution, School of Biological Sciences. University of Sussex, Brighton, United Kingdom, 1999.

[28] C.E. Shannon, W. Weaver, A mathematical theory of communication, The Bell System Technical Journal. 27 (1948) 379-423 and 623-656.

[29] J.C. Jansen, W.G. Arkel, M.G. Boots, Designing indicators of long-term energy supply security, Energy research Centre of the Netherlands (ECN), Petten, The Netherlands, 2004.

[30] APERC, A quest for energy security in the 21st century, Asia Pacific Energy Research Centre: Institute of Energy Economics, Tokyo, 2007.

[31] A. Löschel, U. Moslener, D.T.G. Rübbelke, Indicators of energy security in industrialised countries, Energy Policy. 38 (2010) 1665-1671. doi:10.1016/j.enpol.2009.03.061.

[32] A. Adenikinju, West Africa energy security report, Center for Energy Economics at the University of Texas at Austin, Austin, Texas, 2008.

http://www.beg.utexas.edu/energyecon/IDA/Smart_Development/.

[33] UEMOA, ECOWAS, White Paper for a regional policy: Geared towards increasing access to energy services for rural and periurban populations in order to achieve the Millennium Development Goals, West African Economic and Monetary Union (UEMOA), Economic Community of West African States (ECOWAS), Naimey, Niger, 2006.

[34] UCTE, UCTE system adequacy forecast 2008-2020: Report, Union for the Co-ordination of Transmission of Electricity, Brussels, 2008.

[35] NERC, Reliability assessment guidebook, North American Electric Reliability Corporation (NERC), Princeton, New Jersey, 2010.

[36] G.B. Sheblé, Section 12: Electric power system economics, in: D.G. Fink, H.W. Beaty (Eds.), Standard Handbook for Electrical Engineers, McGraw-Hill Professional, New York, 2006.

[37] IEA, Projected costs of generating electricity, OECD/IEA, Paris, 2010.

[38] O. Rosnes, H. Vennemo, Powering up : costing power infrastructure spending needs in Sub-Saharan Africa : Main text, The World Bank, Washington, D.C., 2009. http://documents.worldbank.org/curated/en/2009/03/14187907/powering-up-costing-powerinfrastructure-spending-needs-sub-saharan-africa-vol-1-3-main-text (accessed March 18, 2015).

[39] S.C. Bhattacharyya, Energy Economics: Concepts, issues, markets, and governance, Springer, London, 2011.

[40] IEA, World energy outlook, OECD/IEA, Paris, 2006.

[41] A. Brew-Hammond, Energy access in Africa: Challenges ahead, Energy Policy. 38 (2010) 2291-2301. doi:10.1016/j.enpol.2009.12.016.

[42] Y. Sokona, Y. Mulugetta, H. Gujba, Widening energy access in Africa: Towards energy transition, Energy Policy. 47, Supplement 1 (2012) 3-10. doi:10.1016/j.enpol.2012.03.040.

[43] S. Pachauri, D. Spreng, Measuring and monitoring energy poverty, Energy Policy. 39 (2011) $7497-$ 7504. doi:10.1016/j.enpol.2011.07.008.

[44] H. Winkler, A.F. Simões, E.L. la Rovere, M. Alam, A. Rahman, S. Mwakasonda, Access and Affordability of Electricity in Developing Countries, World Development. Microfinance: Its Impact, Outreach, and 
Sustainability Including Special Section (Pp. 983-1060) on Sustainable Development, Energy, and Climate Change. Edited by Kirsten Halsnaes, Anil Markandya and P. Shukla. 39 (2011) 1037-1050. doi:10.1016/j.worlddev.2010.02.021.

[45] M. Bazilian, P. Nussbaumer, A. Cabraal, R. Centurelli, R. Detchon, D. Gielen, H. Rogner, M. Howells, H. McMahon, V. Modi, N. Nakicenovic, B. O'Gallachoir, M. Radka, K. Rijal, M. Takada, F. Ziegler, Mearuring energy access: Supporting a global target, The Earth Institute, Columbia University, New York, NY, 2010.

[46] IPCC, Volume 2: Energy - Chapter 1: Introduction, in: Guidelines for National Greenhouse Gas Inventories, Intergovernmental Panel on Climate Change (IPCC), Hayama, Japan, 2006.

[47] IPCC, Volume 2: Energy - Chapter 3: Mobile combustion, in: Guidelines for National Greenhouse Gas Inventories., Intergovernmental Panel on Climate Change (IPCC), Hayama, Japan, 2006.

[48] G. Curci, G. Cinque, P. Tuccella, G. Visconti, M. Verdecchia, M. Iarlori, V. Rizi, Modelling air quality impact of a biomass energy power plant in a mountain valley in Central Italy, Atmospheric Environment. 62 (2012) 248-255. doi:10.1016/j.atmosenv.2012.08.005.

[49] D. Diakoulaki, F. Karangelis, Multi-criteria decision analysis and cost-benefit analysis of alternative scenarios for the power generation sector in Greece, Renewable and Sustainable Energy Reviews. 11 (2007) 716-727. doi:10.1016/j.rser.2005.06.007.

[50] OECD, Key environmental indicators, Organisation for Economic Co-operation and Development (OECD), Paris, 2008.

[51] OECD, Indicators for the integration of environmental concerns into energy policies, Organisation for Economic Co-operation and Development (OECD), Paris, 1993.

[52] E.L.L. Rovere, J.B. Soares, L.B. Oliveira, T. Lauria, Sustainable expansion of electricity sector: Sustainability indicators as an instrument to support decision making, Renewable and Sustainable Energy Reviews. 14 (2010) 422-429. doi:10.1016/j.rser.2009.07.033.

[53] M.F. Torchio, G. Genon, A. Poggio, M. Poggio, Merging of energy and environmental analyses for district heating systems, Energy. 34 (2009) 220-227. doi:10.1016/j.energy.2008.01.012.

[54] IAEA, Energy indicators for sustainable development: Guidelines and methodologies, International Atomic Energy Agency (IAEA), United Nations Department of Economic and Social Affairs, International Energy Agency, Eurostat, \& European Environment Agency, Vienna, 2005.

[55] EPA Ghana, Guidelines development - Volume 2 Report, Environmental Protection Agency, Ghana (EPA), Accra, 2007.

[56] T.J. Feeley lii, T.J. Skone, G.J. Stiegel Jr, A. McNemar, M. Nemeth, B. Schimmoller, J.T. Murphy, L. Manfredo, Water: A critical resource in the thermoelectric power industry, Energy. 33 (2008) 1-11. doi:10.1016/j.energy.2007.08.007.

[57] N.H. Afgan, M.G. Carvalho, Multi-criteria assessment of new and renewable energy power plants, Energy. 27 (2002) 739-755. doi:10.1016/S0360-5442(02)00019-1.

[58] S. Jay, Strategic environmental assessment for energy production, Energy Policy. 38 (2010) 34893497. doi:10.1016/j.enpol.2010.02.022.

[59] D. Turney, V. Fthenakis, Environmental impacts from the installation and operation of large-scale solar power plants, Renewable and Sustainable Energy Reviews. 15 (2011) 3261-3270. doi:10.1016/j.rser.2011.04.023.

[60] F. Ribeiro, P. Ferreira, M. Araújo, Evaluating future scenarios for the power generation sector using a Multi-Criteria Decision Analysis (MCDA) tool: The Portuguese case, Energy. 52 (2013) 126-136. doi:10.1016/j.energy.2012.12.036.

[61] G. Finnveden, M. Nilsson, J. Johansson, Å. Persson, Å. Moberg, T. Carlsson, Strategic environmental assessment methodologies - applications within the energy sector, Environmental Impact Assessment Review. 23 (2003) 91-123. doi:10.1016/S0195-9255(02)00089-6.

[62] Energy Commission of Ghana, Strategic national energy plan (SNEP) 2006-2020, Energy Commission of Ghana, Accra, 2006.

[63] GSS, Gross domestic product 2014, Ghana Statistical Service (GSS), Accra, 2014. http://www.statsghana.gov.gh/docfiles/GDP/GDP_2014.pdf.

[64] EC, Strategic national energy plan 2006-2020, Energy Commission of Ghana (EC), Accra, 2006.

[65] N.W.M. Bishop, J.D. Burton, Technology and implementation issues related to water-pumping windmills, Energy for Sustainable Development. 3 (1996) 44-50. 
[66] I. Dunmade, Indicators of sustainability: assessing the suitability of a foreign technology for a developing country, Technology in Society. 24 (2002) 461-471.

[67] T. Siyambalapitiya, A review of the energy policy in Sri Lanka and its implementation, Energy for Sustainable Development. 6 (2002) 5-13. doi:10.1016/S0973-0826(08)60293-8.

[68] B. Anderson, Barriers to the implementation of coal syngas/polygeneration (CSP) in China, Energy for Sustainable Development. 7 (2003) 25-27. doi:10.1016/S0973-0826(08)60376-2.

[69] M.A.R. Sarkar, M. Ehsan, M.A. Islam, Issues relating to energy conservation and renewable energy in Bangladesh, Energy for Sustainable Development. 7 (2003) 77-87. doi:10.1016/\$0973-0826(08)603579.

[70] J.M. Huacuz, The road to green power in Mexico-reflections on the prospects for the large-scale and sustainable implementation of renewable energy, Energy Policy. 33 (2005) 2087-2099. doi:10.1016/j.enpol.2004.04.004.

[71] P.A. Jó, M. Barry, The most important success factors for implementation of government projects in developing countries, in: PICMET, 2008: pp. 1400-1409.

[72] T. Urmee, D. Harries, A survey of solar PV program implementers in Asia and the Pacific regions, Energy for Sustainable Development. 13 (2009) 24-32. doi:10.1016/j.esd.2009.01.002.

[73] M.A.H. Mondal, L.M. Kamp, I. Pachova, Drivers, barriers, and strategies for implementation of renewable energy technologies in rural areas in Bangladesh- An innovation system analysis, Energy Policy. 38 (2010) 4626-4634.

[74] G.J. Stapleton, Successful implementation of renewable energy technologies in developing countries, Desalination. 248 (2009) 595-602. doi:10.1016/j.desal.2008.05.107.

[75] P. Balachandra, Modern energy access to all in rural India: An integrated implementation strategy, Energy Policy. 39 (2011) 7803-7814. doi:10.1016/j.enpol.2011.09.026.

[76] M.-L. Barry, H. Steyn, A. Brent, Proposal of a framework for the selection of renewable energy technology systems in Africa, in: Proceedings of the World Renewable Energy Congress - Sweden, 813 May, 2011, Linköping, Sweden, 2011: pp. 2562-2569.

[77] S.C. Bhattacharyya, Energy access programmes and sustainable development: A critical review and analysis, Energy for Sustainable Development. 16 (2012) 260-271. doi:10.1016/j.esd.2012.05.002.

[78] J. Krupa, Identifying barriers to aboriginal renewable energy deployment in Canada, Energy Policy. 42 (2012) 710-714. doi:10.1016/j.enpol.2011.12.051.

[79] W. Liu, C. Wang, A.P.J. Mol, Rural public acceptance of renewable energy deployment: The case of Shandong in China, Applied Energy. 102 (2013) 1187-1196. doi:10.1016/j.apenergy.2012.06.057.

[80] FAO, Chapter III - The framework: Implementation. In: A new approach to energy planning for sustainable rural development, Food and Agriculture Organization of the United Nations: Corporate Document Repository. (1990). http://www.fao.org/docrep/t0363e/t0363e00.htm\#Contents (accessed February 18, 2015).

[81] U.S. Congress Office of Technology Assessment, Energy in developing countries, Washington, D.C., 1991.

[82] World Bank, Rural energy and development for two billion people: Meeting the challenge, Vice Presidency for Finance and Private Sector Development Industry \& Energy Department, Washington, DC., 1997.

[83] Suzlon Energy Limited, Small scale wind project design document wind Tamil Nadu. Clean Development Mechanism (CDM) Validation Project. http://cdm.unfccc.int/Projects/Validation/index.html, (2003).

[84] GNESD, Renewable energy technologies and poverty alleviation: Overcoming barriers and unlocking potentials, Global Network on Energy for Sustainable Development (GNESD), Copenhagen, 2007.

[85] Fondation Énergies pour le Monde, Best practices working for success: Rural electrification by renewable energies in Sub-Saharan Africa., Fondation Énergies pour le Monde, Paris, 2007.

[86] U.S. Government Accountability Office, Testimony before the Comittee on Energy and Natural Resources U.S Senate: Recovery act factors effecting the Department of Energy's program implementation: Statement of Patricia A. Dalton., United States (U.S.) Government Accountability Office, Washington, D.C., 2010.

[87] ESMAP, Innovative approaches to energy access for the urban poor: Summaries of best practices from case studies in four countries, Energy Sector Management Assistance Program (ESMAP), Washington, D.C., 2012. http://www.esmap.org/node/1716 (accessed February 18, 2015). 
[88] P. Dembele, PV to Georgia, Sustainable Energy News- Newsletter of the International Network for Sustainable Energy (INFORSE). November (2011) 6.

[89] INFORSE, Access to energy for all - the sustainable way, Sustainable Energy News- Newsletter of the International Network for Sustainable Energy (INFORSE). June (2012) 4-5.

[90] M. Dadiana, PV to Georgia, Sustainable Energy News- Newsletter of the International Network for Sustainable Energy (INFORSE). March (2006) 8.

[91] S. Carberry, Lack of electricity dims afghan economic prospects, All Things Considered, National Public Radio (NPR). (2012). http://www.npr.org/2012/07/02/156119309/lack-of-electricity-dims-afghaneconomic-prospects (accessed February 18, 2015).

[92] E. Hannon, India's huge blackout leaves millions without power, All Things Considered, National Public Radio. (2012). http://www.npr.org/2012/07/30/157613419/indias-huge-blackout-leaves-millionswithout-power (accessed February 18, 2015). 


\section{Appendix A - Identification of factors influential for implementation and}

\section{sustainability}

Articles

1. Bishop and Burton [65]

2. Wicklein [24]

3. Dunmade [66]

4. Siyambalapitiya [67]

5. Anderson [68]

6. Sarkar et al. [69]

7. Huacuz [70]

8. Jó and Barry [71]

9. Urmee and Harries [72]

10. Mondal et al. [73]

11. Stapleton [74]

12. Brew-Hammond [41]

13. Balachandra [75]

14. Barry et al. [76]

15. Bhattacharyya [77]

16. Krupa [78]

17. Liu et al. [79]

18. Sokona et al. [40]

Government, organization, and company reports

19. FAO [80]

20. U.S. Congress Office of Technology Assessment [81]

21. World Bank [82]

22. Suzlon Energy Limited [83]

23. GNESD [84]

24. Fondation Énergies pour le Monde [85]

25. United States Government Accountability Office [86]

26. ESMAP [87]

News articles

27. Dembele [88]

28. INFORSE [89]

29. Dadiana [90]

30. Carberry Sean ([91]

31. Hannon [92] 
(2-column fitting image - in landscape layout)

Fig. A 1. Implementation factors filtering process 


\section{Appendix B - Supplementary tables}

Supplementary data associated with this article can be found as an e-component of the online version at: [Hyperlink for article online]

Table B 1. Technology maintainability levels - Case Study of Ghana

Table B 2. Technology environmental impacts -Case Study of Ghana 
Factors identified in initial

literature review

$$
\text { ( } n=109 \text { ) }
$$

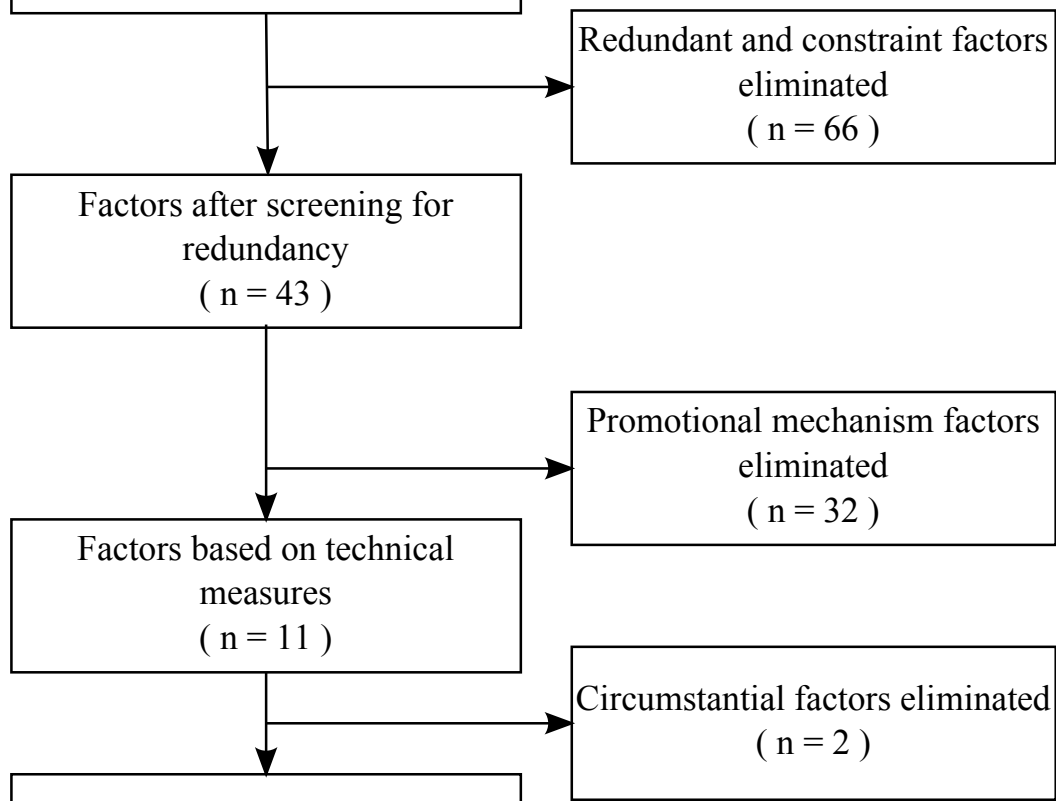

Factors based on fundamental opposed to circumstantial characteristics

$$
(\mathrm{n}=9)
$$

Factors included in the final list to be converted to objectives with similar factors combined $(n=7)$ 


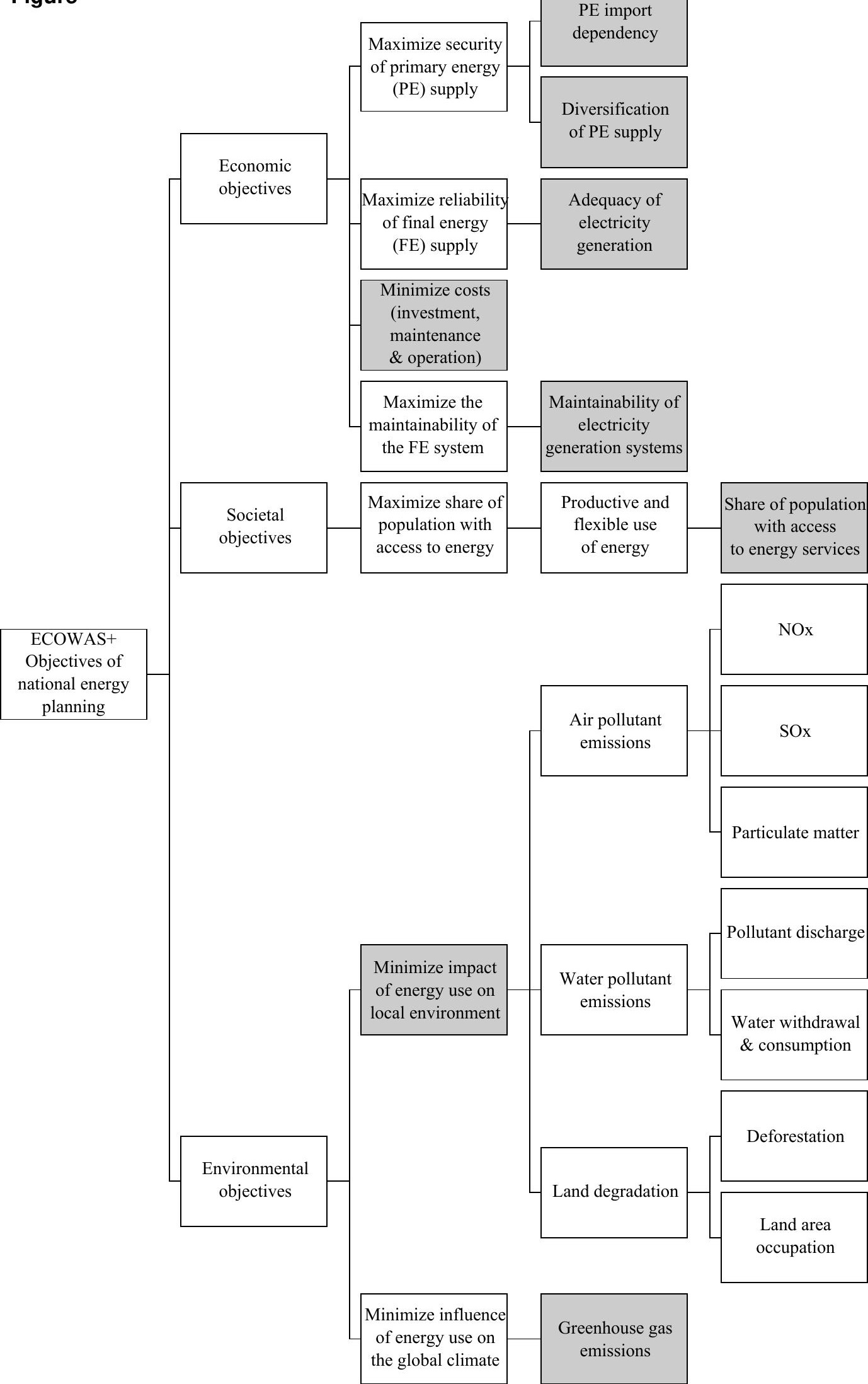


PU, 5 GE suaply Engy (FE) supply
Correct technology for application avail

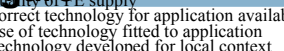
Droven or demonstrated technology
Suitable sites ready for pilot studes
Access to suitable sites is securable ficient after sales service
Avaliabilitiof of warrenties for equipment

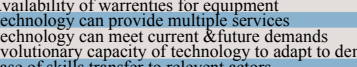
Tase of skills transfer
Time between repairs
Tonple

Compexite of repairs
Availability of system

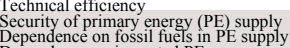

ependence on fossil fuels in
Rependence on imported PE
Reliance on local PE resources
Diversification of PE sources

lows for productive ususeses of energy

Encourages small enterprises or income generating opportunities 9,15
Supports communitit's abililitit to pyy for services \& economic stability 14
Usability among porer pounlations
Risk factor - fit to local produndant with affordability factors \& poorer populations is subjective

Availability of technical know-how \& skilled staff $2,3,4,5,7,9,11,13,15,19,20,26,27$

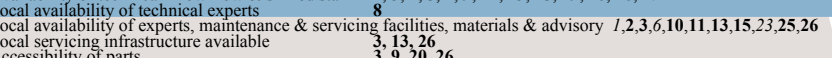

\begin{tabular}{ll} 
Accessibility of parts \\
Reusibility of technology parts & $\mathbf{3}, 9,20,26$ \\
\hline
\end{tabular}

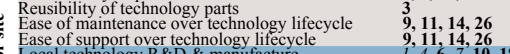

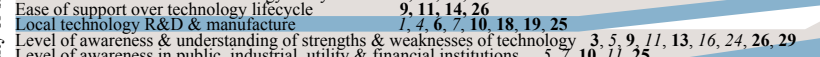

Availability of technical know-how
Availability of maintenance $\&$ servicing resources and facilitie

$$
\text { Local }
$$

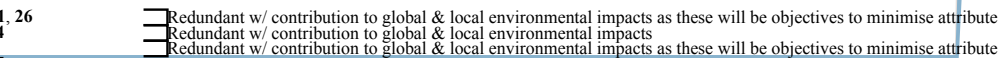
Community involvement
Societal views of importance of technologies Needed infrastructure in place
Education levels of populations

$\exists$

Ease of skills transfer to relevent actors

Security of PE supply

Allows for productive uses of energy

Availability of minnteal know-how

Availability of maintenance \& servicing
resources and facilities
Societal views of importance of technolo

Affordability of system for users - Capital cos

Affordability of system for users - Maintenance \&

Contribution to global climate change

Local environmental impacts

Ability to providect concumers
Ability to protect investors Program, project, invisiness management \& administrative capacity
Gvernment cordination Regulatory cramewowork defining role \& scope of private sector Monitoring \& evaluation activities Docused planning efforts Integrated in multi-isector develolopment tstrategies
Integration between planning and implementing efforts

Cons

\section{Promotional mechanism
Prexisting condition \\ Prexisting condition
Prexisting condition
Promotional mechani \\ Promotional mechanism
Promotional mechanism
Promotional mechanism \\ rexisting condition descriptive or $\mathrm{LP}$ actor capacitic \\ Prexisting condition
Prexisting condition \\ Prexisting condition descriptive of the EP activity
Prexisting condition descriptive of EP actor capacitie \\ Prexisting condition descriptive of EP actor capacities
Prexisting condition descriptive of $\mathrm{EP}$ actor capacities
Prexisting condition descritive of $\mathrm{E}$ actor capacities
Prexisting condition descriptive of $\mathrm{EP}$ actor capacities}

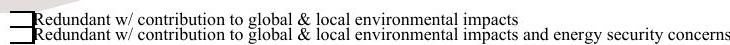
Contribution to ingobacts as these will be objectives to minimise attrib
Local environmental impacts
Reliability of FE

Reliability of FE supply

Security of PE supply

Allows for productive uses of energy Maintainability of energy systems servicing resouices and facilities
Aftordability of system for users - Capital costs
Affordability of system for users Contribution to global climate change Local environmental impacts

Local environmental impacts 
Table 1. List of factors for implementation and sustainability

\begin{tabular}{ll}
\hline Theme & Factor \\
\hline \multirow{3}{*}{ Technology or system } & Security of the primary energy (PE) supply \\
& Reliability of the FE supply \\
& Allows for productive uses of energy \\
& Maintainability of energy systems \\
\hline Economic \& Financial & Investment costs \\
\hline \multirow{3}{*}{ Environmental } & $\begin{array}{l}\text { Contributions to climate change } \\
\text { Impacts on local environment (including air pollution, water pollution and land } \\
\text { degradation) }\end{array}$ \\
\hline
\end{tabular}

Factor 
Table 2. Defined levels of constructed scale of maintainability

\begin{tabular}{|c|c|}
\hline $\begin{array}{l}\text { Attribute } \\
\text { level }\end{array}$ & Representative Maintainability \\
\hline \multirow{3}{*}{ 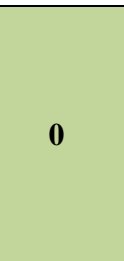 } & $\begin{array}{l}\text { Highly Maintainable: } \\
\text { Proveness: Technologies are proven in area of application with multiple case studies and current use in } \\
\text { energy systems. }\end{array}$ \\
\hline & $\begin{array}{l}\text { Parts and maintenance: All or the majority of general and/or crucial parts are locally available \& or } \\
\text { produced, and local maintenance facilities exist, and other parts are easily encountered abroad. }\end{array}$ \\
\hline & $\begin{array}{l}\text { Local capacity: Existence of local technical capacity for installation, maintenance and use as well as local } \\
\text { educational and research facilities familiar with technologies. }\end{array}$ \\
\hline \multirow{4}{*}{1} & Reasonably Maintainable: \\
\hline & $\begin{array}{l}\text { Proveness: Technologies are proven in geographical area of application with multiple case studies } \\
\text { completed. }\end{array}$ \\
\hline & $\begin{array}{l}\text { Parts and maintenance: A number of general and/or crucial parts and maintenance facilities are locally } \\
\text { available, while the other parts can be found abroad. }\end{array}$ \\
\hline & $\begin{array}{l}\text { Local capacity: Some existence of local technical capacity for installation, maintenance and use, while } \\
\text { technical capacity can be easily found abroad. }\end{array}$ \\
\hline \multirow{4}{*}{2} & Marginally Maintainable: \\
\hline & $\begin{array}{l}\text { Proveness: Technologies are proven in geographical area of application with at least one case study of } \\
\text { application completed. }\end{array}$ \\
\hline & $\begin{array}{l}\text { Parts and maintenance: Some parts and maintenance facilities are available in geographical area of } \\
\text { application, while majority of parts and facilities for maintenance are still found abroad. }\end{array}$ \\
\hline & $\begin{array}{l}\text { Local capacity: Some existence of local technical capacity for installation, maintenance and use, while } \\
\text { majority of technical capacity is found abroad. }\end{array}$ \\
\hline \multirow{4}{*}{3} & Not Maintainable: \\
\hline & Proveness: Technologies are not proven in geographical area of application. \\
\hline & $\begin{array}{l}\text { Parts and maintenance: Parts and maintenance facilities are not available in geographical area of } \\
\text { application. All parts and facilities for maintenance are found abroad. }\end{array}$ \\
\hline & $\begin{array}{l}\text { Local capacity: No local technical capacity for installation, maintenance and or use. All of technical } \\
\text { capacity is found abroad. }\end{array}$ \\
\hline
\end{tabular}


Table 3. Energy carrier portfolios and respective FE services provided in current work

\begin{tabular}{|c|c|c|c|c|c|c|c|c|c|c|c|c|}
\hline \multicolumn{13}{|c|}{ Energy Services } \\
\hline $\begin{array}{l}\text { Energy } \\
\text { carrier } \\
\text { portfolios }\end{array}$ & $\begin{array}{c}\text { Energy } \\
\text { services } \\
\text { provided } \\
\text { [count] }\end{array}$ & Cooking & $\begin{array}{c}\text { Water } \\
\text { heating } \\
\text { (domestic) }\end{array}$ & Lighting & $\begin{array}{c}\text { Water } \\
\text { pumping } \\
\text { (mechanical } \\
\text { power) }\end{array}$ & Refrigeration Freezing & $\begin{array}{l}\text { Clotheswashing } \\
\text { (mechanical) }\end{array}$ & $\begin{array}{l}\text { Computer } \\
\text { \& IT }\end{array}$ & $\begin{array}{l}\text { Clothesdrying } \\
\text { (mechanical) }\end{array}$ & $\begin{array}{l}\text { Dishwashing } \\
\text { (mechanical) }\end{array}$ & $\begin{array}{c}\text { Air } \\
\text { Conditioning } \\
\text { (mechanical) }\end{array}$ & $\begin{array}{c}\text { Entertainment } \\
\text { devices } \\
\text { (electronic) }\end{array}$ \\
\hline $\begin{array}{l}\text { Fuelwood } \\
(\mathrm{FW})\end{array}$ & 2 & $\bullet$ & $\bullet$ & & & & & & & & & \\
\hline $\begin{array}{l}\text { FEW + } \\
\text { Kerosene }\end{array}$ & 3 & $\bullet$ & $\bullet$ & $\bullet$ & & & & & & & & \\
\hline $\mathrm{FW}+\mathrm{LPG}$ & 2 & & & $\bullet$ & & & & & & & & \\
\hline $\begin{array}{l}\mathrm{FW}+\mathrm{Ker}+ \\
\mathrm{LPG}\end{array}$ & 3 & $\bullet$ & $\bullet$ & - & & & & & & & & \\
\hline $\begin{array}{l}\text { Electricity- } \\
\text { Grid (Elec-G) }\end{array}$ & 12 & $\bullet$ & $\bullet$ & $\bullet$ & $\bullet$ & $\bullet$ & $\bullet$ & $\bullet$ & $\bullet$ & $\bullet$ & $\bullet$ & $\bullet$ \\
\hline $\begin{array}{l}\text { Elec-G + } \\
\text { LPG }\end{array}$ & 12 & $\bullet$ & $\bullet$ & $\bullet$ & $\bullet$ & $\bullet$ & $\bullet$ & $\bullet$ & $\bullet$ & $\bullet$ & $\bullet$ & • \\
\hline $\begin{array}{l}\text { Electricity- } \\
\text { Minigrid } \\
\text { (Elec-MG) }\end{array}$ & 12 & $\bullet$ & $\bullet$ & $\bullet$ & $\bullet$ & $\bullet$ & $\bullet$ & $\bullet$ & $\bullet$ & $\bullet$ & $\bullet$ & $\bullet$ \\
\hline $\begin{array}{l}\text { Elec-MG + } \\
\text { LPG }\end{array}$ & 12 & $\bullet$ & $\bullet$ & $\bullet$ & $\bullet$ & $\bullet$ & $\bullet$ & $\bullet$ & $\bullet$ & $\bullet$ & $\bullet$ & $\bullet$ \\
\hline Electricity- & & & & & & & & & & & & \\
\hline $\begin{array}{l}\text { Standalone } \\
\text { (Elec-SA) }\end{array}$ & 12 & $\bullet$ & $\bullet$ & $\bullet$ & $\bullet$ & $\bullet$ & $\bullet$ & $\bullet$ & $\bullet$ & $\bullet$ & $\bullet$ & $\bullet$ \\
\hline $\begin{array}{l}\text { Elec-SA + } \\
\text { LPG }\end{array}$ & 12 & $\bullet$ & $\bullet$ & $\bullet$ & $\bullet$ & $\bullet$ & $\bullet$ & $\bullet$ & $\bullet$ & $\bullet$ & $\bullet$ & $\bullet$ \\
\hline
\end{tabular}


Table 4. Defined levels of constructed scale of impact on local environment

\begin{tabular}{|c|c|}
\hline $\begin{array}{c}\text { Attribute } \\
\text { level }\end{array}$ & Representative local environmental impact \\
\hline \multirow{3}{*}{$\mathbf{0}$} & $\begin{array}{l}\text { No or negligible impact to: } \\
\text { Air quality: No or negligible emissions of air pollutants of concern. }\end{array}$ \\
\hline & Water quality: No or negligible water withdrawal, water consumption, and negligible pollutant discharge. \\
\hline & $\begin{array}{l}\text { Land quality: No or negligible deforestation and no or negligible land area transformation or time period of } \\
\text { occupation. }\end{array}$ \\
\hline \multirow{3}{*}{1} & $\begin{array}{l}\text { Minor negative impact to: } \\
\text { Air quality: Minimal emissions of air pollutants of concern. }\end{array}$ \\
\hline & Water quality: Minimal water withdrawal as well as minimal or no pollutant discharge in water. \\
\hline & $\begin{array}{l}\text { Land quality: Minimal deforestation for energy use, minimal transformation of land, and land occupation is } \\
\text { short. }\end{array}$ \\
\hline \multirow{3}{*}{2} & $\begin{array}{l}\text { Moderate negative impact to local air, water, land quality: } \\
\text { Air quality: Moderate emissions of air pollutants of concern. }\end{array}$ \\
\hline & $\begin{array}{l}\text { Water quality: Moderate water withdrawal and consumption as well as moderate pollutant discharges in } \\
\text { water. }\end{array}$ \\
\hline & $\begin{array}{l}\text { Land quality: Moderate deforestation rate for energy use, moderate transformation of land which has } \\
\text { moderate periods of occupation. }\end{array}$ \\
\hline \multirow{3}{*}{3} & $\begin{array}{l}\text { Major negative impact to: } \\
\text { Air quality: Large quantity of emissions of air pollutants of concern. }\end{array}$ \\
\hline & Water quality: Large water withdrawal and or consumption as well as significant pollutant discharges. \\
\hline & $\begin{array}{l}\text { Land quality: Unsustainable deforestation rate for production of energy, and there is major transformation } \\
\text { of land, with large time period for occupation. }\end{array}$ \\
\hline
\end{tabular}


Table 5. Evaluation of the Reference Projection: Case study of Ghana

\begin{tabular}{|c|c|c|c|c|c|c|c|}
\hline & \multicolumn{7}{|c|}{ Attributes } \\
\hline & 1 & 2 & 3 & 4 & 5 & 6 & 7 \\
\hline & $\begin{array}{l}\text { PE Security } \\
\text { [0=More } \\
\text { security, } \\
\text { 1=Less } \\
\text { security }]\end{array}$ & $\begin{array}{c}\text { Adequacy of } \\
\text { electricity } \\
\text { generation } \\
{[0=\text { Less }} \\
\text { Adequacy, } 1= \\
\text { More adequacy] }\end{array}$ & $\begin{array}{c}\text { Cost: Investment, } \\
\text { Operation \& } \\
\text { Maintenance } \\
\text { [Billion US \$] }\end{array}$ & $\begin{array}{c}\text { Maintainability of } \\
\text { electricity generation } \\
{[0=\text { Highly }} \\
\text { maintainable, } 3=\text { Not } \\
\text { maintainable }]\end{array}$ & $\begin{array}{c}\text { Access to } \\
\text { modern energy } \\
\text { services [0=Less } \\
\text { access, } \\
12=\text { More } \\
\text { access] }\end{array}$ & $\begin{array}{l}\text { Impact on } \\
\text { global climate } \\
{\left[\text { Mton } \mathrm{CO}_{2 \mathrm{eq}}\right.} \\
\text { emissions] }\end{array}$ & $\begin{array}{c}\text { Impact on local } \\
\text { environment }[0=\mathrm{No} \\
\text { or negligible impact, } \\
\text { 3=Major negative } \\
\text { impact }]\end{array}$ \\
\hline $\begin{array}{l}\text { Reference } \\
\text { Projection }\end{array}$ & 0.6173 & 0.1685 & 86.0 & 1.022 & 12.00 & 296 & 2.05 \\
\hline
\end{tabular}


Table B 1. Technology maintainability levels: Case Study of Ghana

\begin{tabular}{|c|c|c|c|}
\hline $\begin{array}{l}\text { Conversion } \\
\text { technology }\end{array}$ & $\begin{array}{l}\text { Maintainability level } \\
\text { [Table 2] }\end{array}$ & Description & Reference \\
\hline Oil & 0 & Decommissioned prior to plan implementation. & (EC 2006) \\
\hline Coal & & No examples in West Africa but common in South Affrica. & (Anku 2012) \\
\hline Gas Turbines & 1 & $\begin{array}{l}\text { and combined cycles (CC) running either on natural gas or on liquid } \\
\text { fuel. The majority of these GT and CC are dual fuel allowing } \\
\text { burning either gas or liquid fuels. Various manufacturers are } \\
\text { represented on the continent. In the base year there was limited } \\
\text { installed capacity in Ghana. }\end{array}$ & (ECOWAS 2011) \\
\hline Combined Cycle & & & \\
\hline $\begin{array}{l}\text { Gas Turbines } \\
\text { (CCGT) }\end{array}$ & 1 & See gas turbines. & \\
\hline Large hydro & 0 & $\begin{array}{l}\text { Large Hydro - highly maintainable as large hydro dams were } \\
\text { constructed in } 1965 \text { in Ghana, and are therefore well established. }\end{array}$ & (EC 2006) \\
\hline Small hydro & 1 & $\begin{array}{l}\text { Here small hydro considered to be less maintainable than large } \\
\text { hydro. Nigeria has installed capacity. }\end{array}$ & (Ohunakin et al. 2011) \\
\hline $\begin{array}{l}\text { Large Wind- } \\
\text { onshore }\end{array}$ & 2 & $\begin{array}{l}\text { Wind installed capacity in Africa is small - both in measured by } \\
\text { installed capacity, and by its contribution to the energy mix. } 96 \% \text { of } \\
1,000 \mathrm{MW} \text { of installed capacity located in North African Countries. }\end{array}$ & $\begin{array}{l}\text { (Mukasa et al. 2013; } \\
\text { GWEC 2014) }\end{array}$ \\
\hline $\begin{array}{l}\text { Large Wind- } \\
\text { offshore }\end{array}$ & 3 & No known Installations in Africa. & \\
\hline Small wind & 2 & $\begin{array}{l}\text { Assumed to have the same maintainability level as Large wind } \\
\text { farms. }\end{array}$ & \\
\hline Solar PV Plant & 2 & $\begin{array}{l}\text { Small solar PV plant was installed in Cape Verde in } 2010 \text {, by a } \\
\text { European company. No known small plants in other ECOWAS } \\
\text { countries. }\end{array}$ & (ECREEE 2013) \\
\hline $\begin{array}{l}\text { Concentrated } \\
\text { Solar Plant }\end{array}$ & 3 & $\begin{array}{l}\text { No installations on the African continent. Projects are planned in } \\
\text { Algeria, Morocco, Egypt and South Africa. In } 2009 \text { the IEA } \\
\text { estimated a maximum installed capacity }<600 \mathrm{MW} \text {, where parabolic } \\
\text { trough and central tower receiver are the most common. Linear and } \\
\text { parabolic dish types have few commercial examples. }\end{array}$ & $\begin{array}{l}\text { (Greenpeace et al. 2009; } \\
\text { IEA 2010b) }\end{array}$ \\
\hline $\begin{array}{l}\text { Stand-alone } \\
\text { Solar (building) }\end{array}$ & 3 & $\begin{array}{l}\text { Considered same as small Solar PV plant as there is some installed } \\
\text { capacity. }\end{array}$ & (EC 2006) \\
\hline Landfill Biogas & 3 & $\begin{array}{l}\text { The vast majority of waste disposal sites in Africa are open dumps. } \\
\text { candfill siting is usually decided based upon factors like access to } \\
\text { collection vehicles rather than electricity generation. Sites lack } \\
\text { minimum design and personnel requirements for biogas use. Some } \\
\text { countries have made improvements to landfill practices in northern } \\
\text { Africa and South Africa. }\end{array}$ & (IEA 2009; Botes 2012) \\
\hline $\begin{array}{l}\text { Municipal solid } \\
\text { wastes }\end{array}$ & 3 & $\begin{array}{l}\text { No known implemented technologies in ECOWAS or West Africa. } \\
\text { Exploratory papers and pilot studies are still underway. }\end{array}$ & $\begin{array}{l}\text { Amoo and Fagbenle } \\
\text { 2013; Ofori-Boateng et } \\
\text { al. 2013; Scarlat et al. } \\
\text { 2015) }\end{array}$ \\
\hline $\begin{array}{l}\text { Biomass and } \\
\text { wood wastes }\end{array}$ & 2 & Some installed capacity in forestry and industry sector SNEP. & (EC 2006) \\
\hline Nuclear & 3 & $\begin{array}{l}\text { South Africa has only installed capacity of } 1,900 \mathrm{MW} \text {. Ghana has } \\
\text { small }(30 \mathrm{~kW}) \text { research reactor. }\end{array}$ & (Nyarko 2007; US EIA \\
\hline $\begin{array}{l}\text { Large Solar PV } \\
\text { Plant }\end{array}$ & 3 & $\begin{array}{l}\text { No known capacity in ECOWAS. First large installation has been } \\
\text { discussed in Ghana with foreign installer. }\end{array}$ & (Ayre 2014) \\
\hline Wave Power & 3 & $\begin{array}{l}\text { Negligible installed capacity worldwide. No installed capacity in } \\
\text { Africa. }\end{array}$ & (IEA-ETSAP 2010) \\
\hline $\begin{array}{l}\text { Tidal-range } \\
\text { Barrage Power }\end{array}$ & 3 & $\begin{array}{l}0.5 \mathrm{GW} \text { installed capacity worldwide. No installed capacity in } \\
\text { Africa. }\end{array}$ & See above \\
\hline $\begin{array}{l}\text { Tidal Stream } \\
\text { Power }\end{array}$ & 3 & $\begin{array}{l}\text { Negligible installed capacity worldwide. No installed capacity in } \\
\text { Africa. }\end{array}$ & See above \\
\hline $\begin{array}{l}\text { Hybrid Diesel \& } \\
\text { Solar Minigrid }\end{array}$ & 2 & $\begin{array}{l}\text { Negligible installed capacity in Ghana, or working examples in } \\
\text { ECOWAS. Diesel generators are common, however hybrid solar is } \\
\text { negligible. }\end{array}$ & (EC 2006) \\
\hline
\end{tabular}


Table B 2. Technology environmental impacts: Case Study of Ghana

\begin{tabular}{|c|c|c|}
\hline $\begin{array}{l}\text { Conversion } \\
\text { technology }\end{array}$ & $\begin{array}{l}\text { Local Env. Impact } \\
\text { level [Table 4] }\end{array}$ & Description \\
\hline Oil & 3 & $\begin{array}{l}\text { - High emissions of air pollutants of concern. } \\
\text { - Moderate withdrawal and consumption of water resources, for cooling, as well } \\
\text { as possibility of moderate pollutant discharges, heat and petroleum products, } \\
\text {-Moderate transformation of land with moderate period of occupation. }\end{array}$ \\
\hline Coal & 3 & $\begin{array}{l}\text {-Moderate withdrawal and consumption of water resources, for cooling, as well } \\
\text { as possibility of moderate pollutant discharges, heat and petroleum products, } \\
\text {-Moderate transformation of land with moderate period of occupation. }\end{array}$ \\
\hline Gas Turbines & 2 & $\begin{array}{l}\text {-Moderate emissions of air pollutants of concern, namely NOx } \\
\text { as possibility of moderate pollutant discharges, heat and petroleum products, } \\
\text {-Moderate transformation of land with moderate period of occupation. }\end{array}$ \\
\hline$C C G T$ & 2 & See Gas Turbines. \\
\hline Large hydro & 3 & $\begin{array}{l}\text {-Major transformation of land for construction and reservoir, transformation is } \\
\text { for extended to indefinite period of time. } \\
\text {-Moderate to Large withdrawal of water for electricity generation. }\end{array}$ \\
\hline Small hydro & 0 & $\begin{array}{l}\text {-No or negligible impact on local air or land quality, } \\
\text {-Negligible water withdrawal and land transformation due to dispersed small } \\
\text { hydro. }\end{array}$ \\
\hline $\begin{array}{l}\text { Large Wind- } \\
\text { onshore }\end{array}$ & 1 & $\begin{array}{l}\text { - No or negligible local air or water quality impact. } \\
\text {-minor transformation of land due to small footprint of technology, and } \\
\text { possibility of continued use of surrounding land. }\end{array}$ \\
\hline $\begin{array}{l}\text { Large Wind- } \\
\text { offshore }\end{array}$ & 1 & $\begin{array}{l}\text {-No or negligible local air or water quality impact. } \\
\text {-Minor transformation of offshore land area and landscape due to small } \\
\text { footprint of technology, and possibility of continued use of surrounding land }\end{array}$ \\
\hline Small wind & 0 & $\begin{array}{l}\text {-Negligible transformation of land due to small footprint of technology, and } \\
\text { possibility of continued use of surrounding land. }\end{array}$ \\
\hline & & -No or negligible local air or water quality impact. \\
\hline Solar PV Plant & 1 & $\begin{array}{l}\text { - Minor transformation of land due to small footprint of technology, and } \\
\text { possibility of continued use of surrounding land. }\end{array}$ \\
\hline $\begin{array}{l}\text { Concentrated } \\
\text { Solar Plant }\end{array}$ & 2 & $\begin{array}{l}\text {-No or negligible local air or water quality impact. } \\
\text {-Moderate transformation of land due to large footprint of technology. }\end{array}$ \\
\hline $\begin{array}{l}\text { Stand-alone } \\
\text { Solar } \\
\text { (building) }\end{array}$ & 0 & $\begin{array}{l}\text {-No or negligible local air or water quality impact. } \\
\text {-No or negligible transformation of land due to large footprint of technology. }\end{array}$ \\
\hline Landfill Biogas & 1 & $\begin{array}{l}\text { 2020: namely NOx } \\
- \text { Minimal withdrawal and consumption of water resources, for cooling, as well } \\
\text { as possibility of moderate pollutant discharges, heat and petroleum products, as } \\
\text { only reaching } 1 \text { to } 3 \mathrm{MW} \text { by } 2020 \text {. } \\
\text { - Negligible to minimal transformation of land with minimal period of } \\
\text { occupation, as landfill is already present. }\end{array}$ \\
\hline $\begin{array}{l}\text { Municipal } \\
\text { solid wastes }\end{array}$ & 2 & $\begin{array}{l}\text {-Moderate emissions of air pollutants of concern, namely NOx, SOx, mercury } \\
\text { compounds, dioxins. } \\
\text {-Moderate withdrawal and consumption of water resources, for cooling, as well } \\
\text { as possibility of moderate pollutant discharges including but not limited to heat, } \\
\text { and petroleum products, } \\
\text {-Moderate transformation of land with moderate period of occupation. }\end{array}$ \\
\hline $\begin{array}{l}\text { Biomass and } \\
\text { woodwastes }\end{array}$ & 2 & $\begin{array}{l}\text {-Moderate emissions of air pollutants of concern, namely NOx, SOx, mercury } \\
\text {-Moderate withdrawal and consumption of water resources, for cooling, as well } \\
\text { as possibility of moderate pollutant discharges including but not limited to heat, } \\
\text { and petroleum products, } \\
\text {-Moderate transformation of land with moderate period of occupation. }\end{array}$ \\
\hline Nuclear & 3 & $\begin{array}{l}\text {-Mo or negligible emissions of air pollutants of concern. } \\
\text { as well as possibility of moderate pollutant discharges, heat and petroleum } \\
\text { products, } \\
\text {-Moderate to high transformation of land with high period of occupation. High } \\
\text { period of occupation of land for nuclear waste disposal and storage. }\end{array}$ \\
\hline $\begin{array}{l}\text { Large Solar PV } \\
\text { Plant }\end{array}$ & 1 & $\begin{array}{l}\text {-No or negligible local air or water quality impact. } \\
\text {-Minor transformation of land due to small footprint of technology, and }\end{array}$ \\
\hline
\end{tabular}




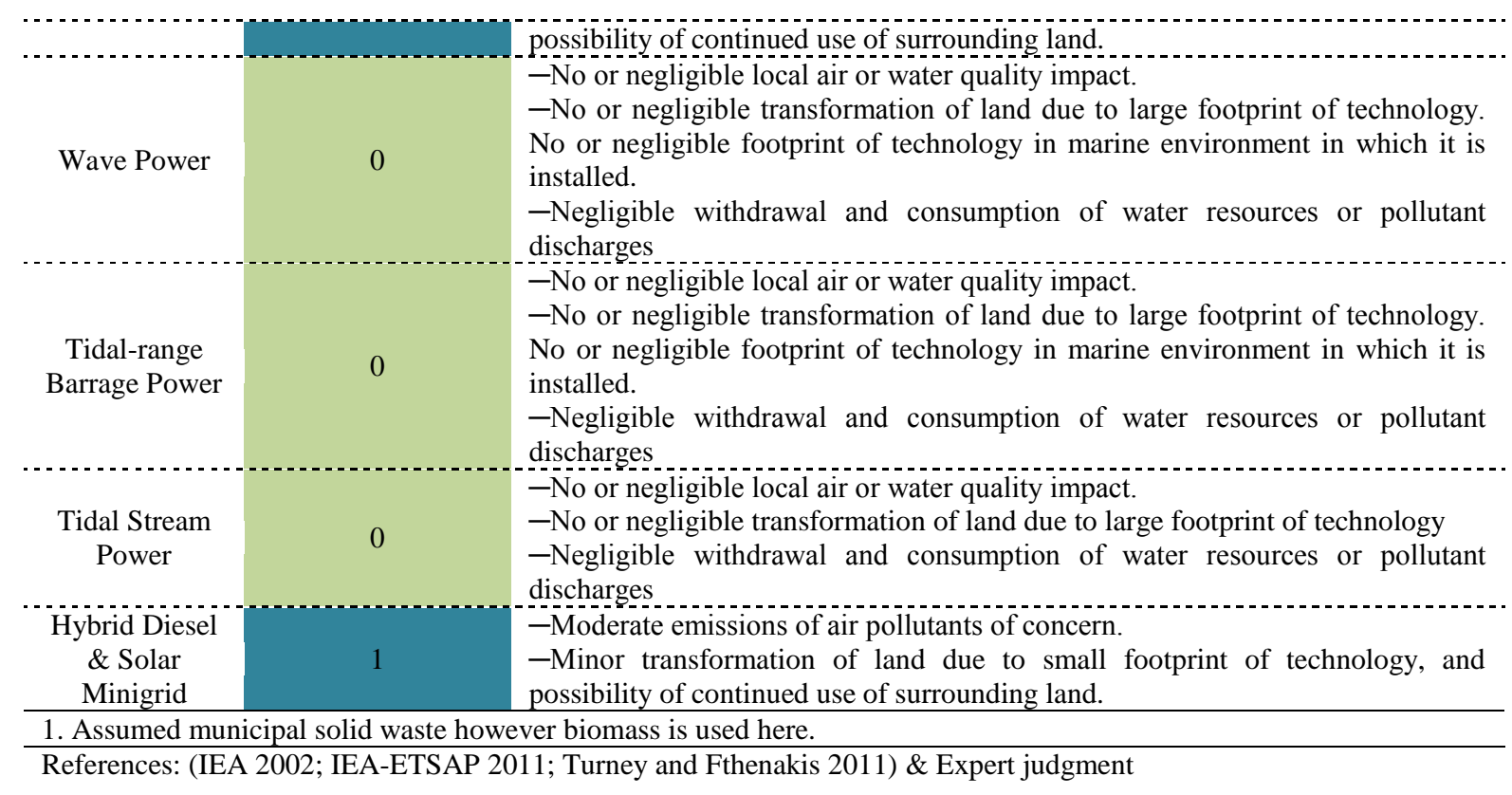

